IZA DP No. 4614

Is Informal Sector Work an Alternative to Workfare Benefits? The Case of Pre-Program Expansion and Economic Crisis

Melanie Khamis

December 2009 


\title{
Is Informal Sector Work an Alternative to Workfare Benefits? The Case of Pre-Program Expansion and Economic Crisis
}

\author{
Melanie Khamis \\ IZA
}

Discussion Paper No. 4614

December 2009

IZA

P.O. Box 7240

53072 Bonn

Germany

Phone: +49-228-3894-0

Fax: +49-228-3894-180

E-mail: iza@iza.org

\begin{abstract}
Any opinions expressed here are those of the author(s) and not those of IZA. Research published in this series may include views on policy, but the institute itself takes no institutional policy positions.

The Institute for the Study of Labor (IZA) in Bonn is a local and virtual international research center and a place of communication between science, politics and business. IZA is an independent nonprofit organization supported by Deutsche Post Foundation. The center is associated with the University of Bonn and offers a stimulating research environment through its international network, workshops and conferences, data service, project support, research visits and doctoral program. IZA engages in (i) original and internationally competitive research in all fields of labor economics, (ii) development of policy concepts, and (iii) dissemination of research results and concepts to the interested public.
\end{abstract}

IZA Discussion Papers often represent preliminary work and are circulated to encourage discussion. Citation of such a paper should account for its provisional character. A revised version may be available directly from the author. 
IZA Discussion Paper No. 4614

December 2009

\section{ABSTRACT \\ Is Informal Sector Work an Alternative to Workfare Benefits? The Case of Pre-Program Expansion and Economic Crisis}

Limited availability of workfare programs and unemployment insurance and a large informal sector are features of the Argentine labor market at the outset of the 2001 economic crisis. This paper tests the hypothesis whether informal work is an alternative to workfare participation before a large-scale program expansion took place. Results from the propensity score matching indicate that observable characteristics of informal low-income workers and current workfare participants are significantly different. However, within these groups, it is possible to identify subgroups that exhibit similar observable characteristics. This indicates that only a subset of the individuals sees workfare and informal sector work as substitutable alternatives.

JEL Classification: J42, J48, O17

Keywords: South America, Argentina, informal labor market, workfare program, propensity score matching

Corresponding author:

Melanie Khamis

IZA

P.O. Box 7240

53072 Bonn

Germany

E-mail: khamis@iza.org

\footnotetext{
* I would like to thank the participants of the workshops at IZA, the World Bank and the conference "Shadow Economy, Tax Evasion and Social Norms" at the University of Muenster 2009. I also would like to thank Armando Barrientos, Oriana Bandiera, Paula Giovagnoli and Diana Weinhold for discussions and comments at various stages of this paper. Moreover, I am grateful to Marcela Salvador for the provision of the eligibility criteria information for Plan Trabajar. All errors are my own.
} 
"In a society in which there is no regular system of unemployment benefit, and in which poor relief is either non-existent or "less eligible" than almost any alternative short of suicide, a man who is thrown out of work must scratch up a living somehow or other by means of his own efforts. And under any system in which complete idleness is not a statutory condition for drawing the dole ${ }^{1}$ a man who cannot find a regular job will naturally employ his time as usefully as he may."

Joan Robinson. 1937. Essays in the theory of employment. London: Macmillan, pp.83-84.

\section{Introduction}

As highlighted by Joan Robinson (1937), in the absence of a regular system of unemployment benefit or support casual and informal work seems the only alternative for survival of the unemployed.

This paper tests the hypothesis that informal waged workers and self-employed with lowincomes are in the informal sector as an alternative to limited available workfare benefits in an economic crisis. ${ }^{2}$

Informal waged workers and the self-employed outside social protection, social insurance and social assistance, and their comparability to workfare participants have not been explored in the empirical literature on program evaluation. Still, this link is quite apparent: Workfare and conditional cash transfer programs are some of the noncontributory safety net programs that can reach the informal sector workers, which do not have access to the formal unemployment insurance system (Vodopivec 2004). For instance, in the case of Argentina in 1991 a system of unemployment benefits was introduced, but it had very little general coverage (Marshall 2004). In Table 1 this point is illustrated with a sample of the unemployed in the October 2001 and 2002 Argentine household survey rounds. Only 2.92 percent and 2.77 percent of the unemployed in 2001 and 2002 respectively received income from unemployment insurance.

\footnotetext{
${ }^{1}$ The "dole" is here used to mean any kind of relief payments.

${ }^{2}$ Informal waged workers are dependent employees that do not have access or rights to a pension. The selfemployed are independent workers and microentrepreneurs, who are bosses of firms with 1-5 employees.

Low-income is meant to be earning at or below the minimum wage of ARG\$ 200.
} 
Alongside the unemployment insurance system, various workfare programs for the unemployed coexist and provide assistance and protection for a large share of the labor force in Argentina (Bertranou and Bonari 2005). With increasing unemployment in the economy, the government introduced these workfare programs from 1993 onwards. Participation in the workfare programs continued to grow after 1998 and peaked after the Argentine economic crisis in 2001/02. The economic situation during that time period is documented with the GDP and GDP growth numbers in Figure 1. From 1998 onwards the Argentine economy was in recession and ultimately experienced a large scale economic crisis, with a sharp drop in GDP growth in 2002 with the devaluation of the Argentine Peso. However, the economic crisis already started the last quarter of 2001 with political, financial and economic turmoil of large-scale proportions. This is also reflected in large increases in poverty and indigence rates and labor market impacts (Khamis 2008).

Informality in the labor market was also another feature of the Argentine labor market during the crisis and beforehand. Over the 1990s also informalisation in the labor market rose and increased substantially after the crisis (Gaspirini 2002; World Bank 2006). A larger segment of informal waged workers, self-employed and workfare participants coexist alongside formal waged workers and the unemployed.

Participation in workfare programs usually is subject to work requirements, which serve to provide incentives in terms of self-targeting and poverty-reducing investments (Besley and Coate 1992). In the presence of low enforcement of some of the workfare programs' eligibility criteria, most noticeably the criteria that participants cannot even hold an informal job before entry into the program or the effort and completion of the work requirement, might be very difficult to monitor in a developing country labor market. ${ }^{3}$ Due to these difficulties, workfare participants might pursue jobs as informal waged workers and self-employed. ${ }^{4}$ Informal waged and self-employed work and workfare program participation could be substitutes or even complements for other household

\footnotetext{
${ }^{3}$ Also the need to monitor the continued eligibility for unemployment insurance and the informal labor market options is raised as an issue by Vodopivec (2004).

${ }^{4}$ Participation in a workfare program might distort incentives to remain or become beneficiaries. It might lead to changed labor market arrangements within the household (Mkandawire 2006). In the case of Argentina this is documented in the re-formation of households, multiple household heads in one family and family splitting (Jalan and Ravallion 1999, 2003).
} 
members and their income.

This paper investigates the hypothesis that in the labor market for low-income individuals the informal sector, more specifically informal waged workers and the self-employed, has a potential substitute role for limited access to workfare programs. ${ }^{5}$

This hypothesis is tested in an environment with limited workfare coverage and general economic recession at the onset of the Argentine economic crisis in 2001, just before the introduction of a near universal workfare program. This analysis provides an insight whether workers from the low-wage informal sector could form a potential entrant group to a more extended workfare program. Using observable characteristics the two groups, the current workfare participants and the control group from the low-wage informal sector are compared with propensity score matching. ${ }^{6}$ Being able to use propensity score matching according to observable characteristics, including the specific eligibility criteria and program participation related characteristics, would provide empirical evidence for the hypothesis that these two groups constitute potential substitutes in the labor market for low-income individuals. Empirical evidence on this is limited as of yet. This paper contributes with a simple test using recent econometric techniques of the program evaluation literature.

In the next section background on workfare programs in Argentina, in particular the eligibility criteria for program participation necessary for the later estimation strategy, is presented. Also the most relevant literature on Argentine workfare programs is discussed in relation to the research presented in this paper. A discussion of the chosen empirical methodology and data follows. Propensity score matching with different comparison groups and the treatment group, workfare participants, is employed in this context.

The main finding of this paper is that observable characteristics of informal low-income workers and current workfare participants are significantly different. However, within these groups, it is possible to identify subgroups that exhibit similar observable characteristics. This indicates that only a subset of the individuals sees workfare and

\footnotetext{
${ }^{5}$ It is harder to check whether workfare participants work parallel to their workfare program work as the workfare participants are coded in differential ways in their work status in the Argentine household survey. Sometimes, in the supplementary survey of Plan Jefes y Jefas de Hogares (the main workfare program after the Argentine economic crisis 2001/02), they are coded as part of salaried employees or unemployed or inactive. This depends on the status and level of their work requirement and the receipt of the work benefit.

${ }^{6}$ This analysis does account for observable characteristics but not unobservables.
} 
informal sector work as substitutable alternatives. In addition to that I find that only 10 percent of the minimum wage, around 20 Argentine Peso, can be accounted to the workfare program as impact when using the informal sector as comparison group.

In the latter sections of this paper these results and its implications for policy are discussed in detail.

\section{Workfare programs: Eligibility Criteria and Informality}

\subsection{History and Eligibility criteria}

Since the early 1990s several workfare programs, which all were targeted at the leastskilled unemployed workers, with a small monthly benefit and work or training requirement in return were implemented by the Argentine government. The main intended objectives were to provide a short-term safety net during times of economic recession and to increase the employability of the unemployed.

These programs were available on the national and provincial level in Argentina. Programa Intensivo de Trabajo, Plan Trabajar I, II, III and Plan Jefes y Jefas de Hogar were the major national employment programs implemented successively throughout the 1990s to $2005 .^{7}$

In 1993 Programa Intensive de Trabajo (PIT) was introduced and targeted at the longterm unemployed household heads. Beneficiaries were required to work on basic infrastructure projects and were able to claim this benefit for six month with an extension possibility for another six months (Bertranou and Bonari 2005).

Following PIT and after the 1995-96 recession, which led to substantial increases in unemployment among the poor and non-poor, Plan Trabajar I was implemented in March 1996. It was subsequently extended until 2002 (Plan Trabajar I to Plan Trabajar III). From Plan Trabajar I onwards the eligibility criteria were amended in order to insure closer targeting of poorer households more closely. The requirement 'to be a household head or to have young dependents' was dropped to allow more general access for the unemployed poor and vulnerable (Eisenstedt 1998).

In general persons older than 16 years of age who were unemployed and poor were able to benefit and receive about or below ARG\$ 200 Peso (Ronconi 2002; Jalan and

\footnotetext{
${ }^{7}$ Other smaller programs are described in Bertranou and Bonari (2005) and Ministerio de Economia (2006).
} 
Ravallion 1999). Thus, the benefit of Plan Trabajar was set at or below the prevailing minimum wage and therefore ensured self-targeting of beneficiaries (Jalan and Ravallion 1999). ${ }^{8}$ In return the participants were required to work in community projects relating to basic infrastructure and community services. Eligible participants were able to receive the benefit for six months (Ministerio de Trabajo y Seguridad Social 1998).

After the economics crisis, in April 2002, Plan Jefes y Jefas de Hogar was put in place to assist Argentines, who experienced a rise in individual poverty rates from 35.9 percent in May 2001 to 53 percent in May 2002 (Khamis 2008). This program continued until the end of 2005, when a transition and reassignment of Plan Jefes y Jefas de Hogares beneficiaries to Familias, a conditional cash transfer program, started and continued in 2006 (World Bank 2006). To be eligible for the receipt of Plan Jefes one needed to be an unemployed head of household with children under 18 years or disabled children in the household. ${ }^{9}$

The work requirement for participants was set at a minimum of four hours per day and maximum of six hours per day. The activity could be working on community projects or basic community work. Also training or finalization of formal education in the form of school attendance was counted towards this requirement. Also participants, that found work in private companies, were entitled to receive the benefit in the form of a wage subsidy for six months. Participants received ARG $\$ 150$ Peso monthly. ${ }^{10}$

Registration to the program was cross-checked with administrative records on social security contributions to see whether workfare applicants were working in the formal sector (Galasso and Ravallion 2003; Giovagnoli 2005; Gasparini, Haimovich and Oliveri 2006). Contrary to this, it was much harder to check whether an applicant was working in the informal sector, as an informal waged worker or self-employed, beforehand or even

\footnotetext{
${ }^{8}$ Coady, Grosh and Hoddinott (2004) discuss issues of Argentina's Plan Trabajar targeting and find that it was able to transfer 80 percent of program benefits to the poorest quintile. The maximum wages paid was set at the minimum wage initially but was adjusted to a lower level at a later stage, which ensured the targeting towards the poorest in the population.

${ }^{9}$ The precise eligible criteria were available on the Argentine Ministry of Labor website on the beneficiaries of Plan Jefes de Hogar: http://www.trabajo.

gov.ar/jefes/beneficiarios/index.asp, (accessed 8th March, 2007) and MTSS (2004).

${ }^{10}$ Modolo (2004) describes in detail institutional, political and social dimensions of the workfare program, which are not discussed here.
} 
parallel to workfare benefit receipt.

Plan Jefes program was almost universal by October 2002, which meant that most people self-selected into the program as participant or applicant, but not everyone was formally employed and then unemployed who received the benefit. Some leakages of the benefit to previously inactive and informal workers were recorded (Galasso and Ravallion 2003, 2004).

Overall, the different workfare programs, Plan Trabajar I to III and Plan Jefes y Jefas de Hogar, described in this section were the largest national programs at the time and share similar general eligibility criteria:

Self-targeting at a low benefit, below minimum wage levels, and a work requirement in some form or another. The beneficiary's previous labor market status was supposed to be unemployed and not in formal work at the time of the workfare benefit application.

Still, this left some potential for targeting inefficiencies: applicants and participants with informal waged work or in self-employment could apply or participate in the workfare program.

\subsection{Workfare programs and Informality}

The vast literature on Argentine workfare programs has centered on several elements: program impact evaluation and program incentives relating to political economy and program inefficiencies. ${ }^{11}$ This section describes a more narrow literature on workfare programs and informality in Argentina and highlights the existing gaps in the literature with respect to the empirical analysis of the low-waged informal and self-employed labor

\footnotetext{
${ }^{11}$ For evaluations of the various workfare programs and their dimensions on employment and poverty: (Galasso and Ravallion 2003, 2004; Galasso, Ravallion and Salvia 2001; Jalan and Ravallion 1999, 2003; Ravallion, Galasso, Lazo and Philipp 2001; Ronconi, Sanguinetti and Fachelli 2004; Ronconi, Sanguinetti, Fachelli, Casazza and Franceschelli 2006; Gasparini, Haimovich and Oliveri 2006; Almeida and Galasso 2007; Iturriza, Bedi and Sparrow 2008). For the political economy literature: The distribution of benefits is analyzed on various levels. On the individual level the administration of benefits is not only directly to the participants, but several intermediaries might be able to take a share of the benefit and exert political pressure on participants (Galasso and Ravallion 2003; 2004; Lodola 2003). Piquetero organizations, which stage road blocks in order to receive workfare program benefits, also have the control of some share of the benefits (Ronconi and Franceschelli 2005). Provinces and municipalities close to certain political parties might also be able to influence the distribution of the workfare benefit (Lodola 2003; Giovagnoli 2005; Weitz-Shapiro 2006).
} 
market in relation to workfare program participants.

Several findings on labor market informality and its relationship with workfare programs are raised in the previous literature relating to workfare programs in Argentina.

In an analysis of Plan Jefes and its impact, using the national household survey for 2001 and 2002 for probit estimations, Paz and Zadicoff (2003) claim that informal workers have more chances to become participants in Plan Jefes than the unemployed and thereby informality is fostered. Relating to this point Galasso and Ravallion (2003, 2004) also argue that previous unemployment status of workfare participants is hard to verify with a high degree of informality in the economy present. Using data for 2001 and 2002 they estimated the workfare program impact with a counterfactual comparison group based on a matched of Plan Jefes applicants, who did not receive the program yet. Despite some problems of eligibility and coverage of the workfare program they conclude from their difference-in-difference estimations that the program helped to reduce unemployment and alleviate poverty.

Another major workfare program evaluation by Ronconi et al. (2004, 2006) employs household survey for the period 2000 to 2002 to evaluate the impact of not only Plan Jefes but also other workfare programs on poverty and employment. They work with a propensity score matching estimator, without the particular focus on informality. Their results are in line with Galasso and Ravallion (2003, 2004) in terms of findings with respect to the program impact and targeting nature of the program. In addition to that they find that the workfare programs operated more as unemployment insurance for beneficiaries and not as a training program as participants who were offered a job in the labor market exited the program.

Investigating informality and workfare program exits Gasparini, Haimovich and Oliveri (2006) employ a matching difference-in-difference estimator for their analysis of the period 2003 to 2005. They find that the design of the workfare program Plan Jefes increased the incentives for current participants to find a job in the informal sector and thereby resulted in an informality bias of the program.

In this paper the focus differs from the existing literature with the emphasis on workfare program participants and a comparison to eligible labor force participants in informal waged work without benefits and self-employed in the low-income sector at a time before 
program universality. Contrary to Gasparini, Haimovich and Oliveri (2006) I do not look at the program exits, but at comparability between participants and low-income informal sector work in a situation of limited program access. The informal labor market and program participation were not incorporated in these studies as potential substitutes.

The importance of the informal sector for unemployed workers as an alternative to the workfare program as a source of income is important. This seems in particular relevant given the limited coverage of the Argentine unemployment insurance system (Vodopivec 2004; Gill, Montenegro and Doemeland 2002). In the absence of the availability of a workfare program the unemployed, the informals and inactive would have to refer to work in the labor market. In the light of the economic crisis in 2001/02 informal sector jobs were found to be one of the main coping strategies (Fiszbein, Giovagnoli and Aduriz 2002). The poor, which do not have access to savings, other resources or social capital, would have to resort to the informal sector for survival if a workfare program was not available to them.

Contrary to the previous literature on informality and workfare programs in Argentina, this paper focuses on the period, October 2001, at the brink of the economic crisis and before the implementation of the near universal Plan Jefes program. An explicit empirical test of the comparability of workfare participants and informal workers and the selfemployed with low-income is proposed in this paper.

\section{Data and Empirical Strategy}

\subsection{Empirical Strategy}

To test the role of being employed in the informal sector as an alternative to workfare participation, this paper estimates with nearest neighbor propensity score matching whether informal workers and self-employed and workfare participation exhibit similar observable characteristics or not. In recent empirical literature on development several papers have employed this technique to compare informal and formal workers' wage gaps (Pratap and Quintin 2006; Badaoui, Strobl and Walsh 2008). Also a related paper on workfare program, which analyses the exits of the workfare program, uses matching techniques (Gasparini, Haimovich and Oliveri 2006).

Here, the focus is different: the comparison of current informal workers and self- 
employed with low income to current workfare participants. ${ }^{12}$

This paper employs propensity score matching for these two groups. ${ }^{13}$ The workfare participants constitute the treatment group $\mathrm{T}$ while the informal sector workers and selfemployed with low income the control group $\mathrm{C}$. As we are not able to observe the treatment group in its counterfactual state of non-treatment and the control group in its counterfactual state of treatment, the econometric method of matching on observables provides a way to construct an observationally equivalent group of informal sector participants to the treatment group of workfare participants.

To implement matching and estimate the impact of treatment, propensity score matching requires two crucial underlying assumptions: the Conditional Independence Assumption (CIA from now onwards) and the Common Support Assumption.

The CIA states that all the relevant differences between two individuals in the treated and in the control group are captured in their observable characteristics $\mathrm{X}$ and those affect participation in the treatment and outcomes. Treatment status is conditional on those observable characteristics:

$\left(Y_{T}, Y_{C}\right) \perp D \mid X$

This underlying assumption is crucial and cannot be tested as such. A potential source of bias, which Bundell and Dias (2000) point out, is the selection on unobservables, which I do not account for here. ${ }^{14}$

The common support condition (equation 2) assumes that participants can be matched to the non-participants with the same characteristics. The support of the distribution is the set of values with positive density.

$0<\operatorname{prob}(D=1 \mid X)<1$ for all $X$

\footnotetext{
${ }^{12}$ In a developed country context, but relevant to this paper, caseworkers and the unemployed are compared for similar characteristics through matching methods (Behncke, Froelich and Lechner 2009).

${ }^{13}$ For an overview on propensity score matching see Caliendo and Kopenig (2008).

${ }^{14}$ To overcome this matching is often combined with a difference-in-difference estimator (Heckman, Ichimura and Todd 1997; Heckman, Lalonde and Smith 1999). Due to the nature of the program, which was expanded substantially in the period following my analysis, this will not be possible to implement it here.
} 
It follows from the common support that it is possible to estimate the average treatment of the treated from the average outcome from the non-treated, which is used as the counterfactual in this case, given their similar observable characteristics.

Both assumptions so far have highlighted the importance of the characteristics $\mathrm{X}$. Rosenbaum and Rubin $(1983,1984)$ propose the use of the propensity score instead of the characteristics $X$ themselves (equation 3). They define the propensity score as the conditional probability of assignment to a particular treatment given a vector of observed characteristics (Rosenbaum and Rubin1983, p.1; Rosenbaum and Rubin 1984, p.1).

$P(X)=\operatorname{prob}(D=1 \mid X)$

Rosenbaum and Rubin $(1983,1984)$ show that the CIA assumption still holds when using the propensity score of the observed characteristics instead of the covariates $\mathrm{X}$ themselves:

$\left(Y_{T}, Y_{C}\right) \perp D \mid P(X)$

Propensity score matching requires a specific range of the propensity score for the treatment and the comparison group to be defined. For this reason, several matching methods, for instance one-to-one, nearest neighbor, kernel, are most commonly used.

As Bundell and Costa Dias (2000) suggested, the nearest neighbor matching estimator can be written as follows:

$\hat{\theta}_{M M}=\sum_{t \varepsilon T}\left(Y_{t}-Y_{c}\right) \frac{1}{N_{T}}$

where observation $\mathrm{c}$ is the nearest neighbor of the comparison group $\mathrm{C}$ in terms of the propensity score to observation $t$ in treatment group $\mathrm{T}$. $\mathrm{N}$ represents the number of nearest neighbor specified. This estimator is applied here to test the hypothesis that informal wage workers and self-employed with low-income are potential workfare program entrants and are observationally similar. To find supporting evidence, being able to match the treatment and control group, for this hypothesis would imply that the main limitation to access the workfare program is the limited availability and not their 
eligibility and characteristics. If it is possible to match these two groups, one can estimate impact of the treatment, workfare program participation, the average treatment on the treated effect (ATT).

Matching accounts for the selection on observables such as individual, household or region characteristics which might influence program participation. It also controls for observable heterogeneous returns. Matching estimators would only compare people who would be comparable due to the common support assumption when matching on the propensity score. For this reason it is possible to determine whether the impact results are reliable or not (Sianesi 2004)

The disadvantage would be that a great sample size is necessary to operationalize matching and that the selection on the observables is highly dependent on the quality of $\mathrm{X}$ used in the matching procedure. The matching quality can best tested through a balancing of variables test, usually a t-test on the equality of the means in the treated and non-treated groups before and after the matching (Sianesi 2004).

For the matching to be successful it is necessary that there is enough common support between the two samples. Hence, the densities of the propensity scores for treatment and control group overlap. Smith (2000) emphasizes this so-called "support" problem. It can happen that the participants sample and the non-participants sample will not have any observations for certain values of $\mathrm{P}(\mathrm{X})$. This would imply that the two samples differ.

For a successful estimation of the treatment one would need an analogue for each of the participants in the non-participant sample. To impose the common support one would drop the treatment observations whose propensity score is higher than the maximum or less than the minimum propensity score of the controls.

In addition to that if treatment impact differs across the treated, the restriction to the common support might change the parameters estimated and it would be impossible to identify the average treatment on the treated effect (Smith 2003).

To check for heterogeneous effects of the workfare program it is possible to divide the sample into subsamples and to check whether results are robust or differ. This was implemented in this paper with different comparison groups, in order to see whether the informal workers and self-employed can form a valid comparison group as opposed to other comparison groups. 
As highlighted before the challenge is the appropriate selection of $\mathrm{X}$ variables in the estimation of the propensity score is important for the identification. For this reason the estimations will include variables that are thought to be related to the eligibility criteria and that determine participation in the program.

\subsection{Data}

Like previous studies on the Argentine labor market (Gasparini 2002; Pratap and Quintin 2006), this paper works with the national household survey, the Encuesta Permanente de Hogares (EPH). The EPH was collected twice a year, in May and October, until May 2003, by the Argentine national statistical office (INDEC). This rotating panel survey covered the major urban areas and thereby about 70 per cent of the Argentine population. Two questionnaires, an individual and household questionnaire, were administered to cover income, benefits receipts, demographic, dwelling, occupation, education and labor market characteristics.

This paper works with the October wave of the 2001 EPH survey, at the outset of the economic crisis and pre-Plan Jefes survey, for the nearest neighbor propensity score matching for comparison (informal sector workers with low wages/income) and treatment group (workfare participants). Construction of the variables for the estimation of the propensity score, the probability of program participation, are derived from the eligibility criteria and knowledge of the workfare programs in Argentina, which were outlined in the previous section.

The availability of questions in the EPH survey limits the different individual, household and regional characteristics to be included in the estimation. Also in the October 2001 wave of the EPH survey the question whether the individual participates in a workfare program was asked, which was used to construct the treatment group in the estimations. One limitation and caveat here in this analysis is the fact that the question relating to workfare programs does not ask which specific program the individual participates and works in.

As there are several national and regional workfare programs ongoing at the time of the household survey, a concern might be the possibility of the respondents participating in different programs. This could potentially introduce some measurement error into the treatment group measure due to potentially slightly different eligibility criteria. However, 
as the main eligibility criteria across different workfare programs were the same as highlighted beforehand and at the time of October 2001 Plan Trabajar III was the largest national workfare program, this problem does not seem to be large.

Hence, the question in the household survey whether the individuals works as part of a workfare program or not determines the classification of the treatment group. To test the validity of the informal workers in paid employment and the self-employed as possible comparable group to the treatment group, different comparison groups were constructed from the information in the household survey. In the next section these results are explained in detail.

\section{Results}

In the following section the three different comparison groups are described and thereafter the results for the propensity score matching for the comparison groups are discussed, with particular focus on the variables included in the propensity score, the details of the matching process in terms of common support and matching quality and also the average treatment effect on the treated (ATT).

\subsection{Potential Comparison Groups}

Viewing the unemployed, the self-employed and informal waged workers in terms of their access to social protection is crucial in this analysis. ${ }^{15}$ As the social protection status is highly dependent on the labor market status at the time and on the labor market history of the individual, it is possible to look at the unemployed, the self-employed and informal waged workers as a group with limited or no access to social protection, but potentially eligible for social assistance programs, such as workfare programs (Bertranou and Bonari 2005). For Argentina Bertranou and Bonari (2005) classify three groups in the labor force for their social protection analysis when looking at unemployment insurance and workfare programs:

Formal workers with permanent status form one of the groups, unemployed and informal/self-employed workers with low-income is another group and the third group is an intermediate group which alternates between self-employed, employee and

\footnotetext{
${ }^{15}$ The sample sizes of the adult population, the unemployed, self-employed, informal workers and workfare participants are provided in the annex.
} 
unemployed status.

To create a comparison group for the workfare participants, this categorization, the eligibility criteria and details of the workfare program, as mentioned previously, were taken into account.

The following three comparison groups $(1,2,3)$ were compiled:

- Group 1 includes the eligible labor force, the unemployed, informal and selfemployed without unemployment benefit and not in formal work. This provides a very general category and the broadest comparison group from the three groupings for the workfare participants.

- Group 2 is constructed more restrictive than Group 1. Here, the eligibility criteria from the workfare program and the element of self-targeting were taken into account. The benefit of the program is below the minimum wage (Jalan and Ravallion 2003). Only individuals with income at or below the level of the minimum wage of ARG\$ 200 peso were taken into account for this group.

- Group 3 restricts this even further as only informal workers and the self-employed, following partly the classification of Bertranou and Bonari (2005) for Argentina, are considered. In this case, the informal workers and the self-employed with low income (below or at the minimum wage), that are eligible for the workfare program, form the comparison group

In Table 2 the summary statistics for the three different comparison groups is presented. ${ }^{16}$ As for the comparison group the most restrictive, Group 3, was chosen while the other comparison groups, group 1 and 2, were used in the robustness checks of the results. Employing Group 3 as comparison group to the workfare participants allows to test the initial hypothesis proposed in this paper.

\subsection{Comparison group: Informal waged workers and the self-employed with below or at minimum wage earnings}

To compare workfare participants and the constructed comparison group of low-income informal workers and self-employed eligible for workfare program, we employ single nearest neighbor propensity score matching for these two groups.

\footnotetext{
${ }^{16}$ Summary statistics for the workfare participants, informal workers, self-employed, the unemployed and the adult population are in the annex.
} 
The probit model to estimate their probability of participation (the propensity score) includes different individual, household and regional characteristics (Table 3).

The dependent variable is a dummy for whether the individual participates in the workfare program 1 or not 0 . The other characteristics included are selected closely related to the eligibility criteria and the description of the program, which included certain characteristics (see section 2). Age, gender, head of household and marital status are included as individual level characteristics and its potential to determine individual participation. In particular, age restrictions to participation and also restrictions to being the household head are relevant as they are relevant and eligibility criteria to participate in the program. The education level is included as different levels of completed or not completed education might play a role in the likelihood to participate in the program. ${ }^{17}$ The household characteristics (number of members and children, living arrangements) are included as important determinants of participation. Having children in the household was one of the eligibility criteria at least initially invoked in Plan Trabajar. ${ }^{18}$ Infrastructure problems, non-access to services and other relevant characteristics of shantytowns in Argentina, most commonly known as 'villa miseria', are included. Any problems with access to water, sewerage, electricity, a sanitary bathroom and unstable building material of the house were seen as indicator for living in a shantytown. Given that the Plan Trabajar's design aimed at individuals self-selecting into the program, which were centered around public works projects relating to the development of local infrastructure, residence in the poor urban areas and provinces are relevant variables to determine program participation (Jalan and Ravallion 1999, 2003). For this reason also regions were included in the estimation, with the area of Greater Buenos Aires being the base. ${ }^{19}$ Many of these variables were also included in the earlier literature on program impact evaluation in Argentina (Jalan and Ravallion 1999, 2003; Galasso and Ravallion

\footnotetext{
${ }^{17}$ Savanti and Patrinos (2005) document the rising returns to schooling in Argentina over the period 19922002. In particular, they find evidence of increases in the earnings premium to complete secondary and complete/incomplete tertiary education.

${ }^{18}$ As pointed out in section 2 eligibility criteria were amended for Plan Trabajar at several occasions and here the most relevant potential criteria are included.

${ }^{19}$ Pampeana, Cuyo, Patagonia, Northeast (NEA in tables) and Northwest (NOA in tables) are the other regions.
} 
2003, 2004; Ronconi et al. 2004, 2006; Gasparini, Haimovich and Olivieri 2006). In Table 3 I include these variables in a probit regression. Age, gender, number of primary household members, location in terms of province and shantytowns were found to be significant determinants of program participation. Education levels, marital status and number of children and living arrangements were not significant in this model. The treatment and control group can be matched on some of the observables while others were not significant predictors of the probability of workfare participation. The propensity score derived from the entire vector of covariates was estimated and obtained for both control and treatment group. Figure 2 plots the densities of the propensity scores for both and one still finds an overlapping large common support. The results of the matching show that most observations of the treatment group are on the common support and only very few treatment observations are dropped (Table 4). Based on the matched sample of controls and treatment, the program impact on individual income for the treated (ATT) can be estimated (Table 5). The individual income variable is monthly individual income, from labor and non-labor sources. The income difference between the treated and the untreated was significant and positive. Participation in a workfare program had an individual income impact of an additional 20 Argentine Peso per month for the average 'treated' person if one compares the low income group of workfare participants and informal and self-employed earning a low income. This is only about 10 percent of the minimum wage at the time. The estimate of the program impact, the ATT, is only as good as the matching quality. A test of the balance of the covariates was performed. This t-test compares the equality of the means in the treated and non-treated groups before and after the matching (Table 6). It is possible to see that the unmatched means exhibit a significant difference in the means while the matched treatment and control group do not have a significant difference in the means for most covariates. ${ }^{20}$ Overall, these results suggest several important insights: First, it is possible to match a treatment group of workfare participants and informal sector participants as control with nearest neighbor propensity score matching and a program impact is estimated. Second, not all observable characteristics are predicators of program participation, when using

\footnotetext{
${ }^{20}$ Also it is found that the bias in the sample was reduced substantially. Results for the absolute bias before and after the matching can be found in the annex.
} 
these treatment and control groups. From these results it is possible to conclude that observable characteristics are still significantly different for the entire two groups and only a subset of workfare participants and informal sector participants exhibit similar characteristics. Hence, only a subset of individuals from the low-earning informal segment of the labor market is comparable to the workfare participants and sees this as a substitutable alternative.

\subsection{Other comparison groups ${ }^{21}$}

The less restrictive comparison groups, Group 1 and Group 2, are also estimated in the propensity score matching procedures. It is found that the significance of the variables included in the probit model, which estimates the propensity of participation in the program, differs slightly compared to Group 3. More variables such as education variables, more regions and number of children in the household are significant predictors of participation in the workfare program than in the Group 3 case.

Also the ATT, when using these groups as comparison, is significant and larger than when the estimation is performed with Group 3 as comparison group.

This again can be taken as an indication that workfare participants are not only sourced from the informal sector, and if from this sector only from a subset. Participants are comparable to the broader eligible labor force and the ones with low-income as well and have a considerable amount of observable characteristics in common with these groups.

\section{Conclusion}

Previous work on program evaluation provided some evidence on targeting leakages to informal workers and the inactive population (Ravallion and Galasso 2003) while this paper highlighted the need to analyze pre-program expansion the potential participants from the informal and self-employed sectors for which inactivity or unemployment for lack of unemployment insurance is not a feasible option for survival.

This paper tested whether a group of informal low-waged workers and the self-employed with low-income and a group of workfare program participants exhibit common observable characteristics and so are comparable. The unemployment insurance and

\footnotetext{
${ }^{21}$ Results for Comparison Group 1 and 2 are in the annex. The focus of this paper is on the Group 3 as the control/comparison group.
} 
workfare program access for the time period under consideration is limited, prior a largescale implementation of a workfare program, and the economic situation worsens from a recession into a crisis. The finding of comparability, with a simple test with single nearest-neighbor propensity score matching with replacement, implied a substitution effect for a sub-group of the informal workers: Instead of earning a low-income a subgroup of informal waged workers and the self-employed could be potential entrants to an expanded workfare program, while currently working in the low-income informal and self-employed labor market to earn a living, in the absence of access to social protection. The construction of the comparison group was restricted to the non-participant population and its subgroup of informal employees and the self-employed, with wages and incomes less or equal to the workfare benefit. One concern here could be that this is already a selection on observable characteristics. However, this just restricts the non-participant population to a population that fulfils the general eligibility criteria of not earning a certain amount of income before the program (in this case at or below the minimum wage) and does not have access to the program. This criticism would also apply to other studies on program evaluation as well, which restrict comparison groups from the general survey population in some form, for instance to labor force participants, before the analysis (Galasso and Ravallion 2003; Ronconi, Sanguinetti and Fachelli 2004).

Here, the comparison and the treatment group exhibited a large common support and then matching along the observable characteristics, which determined participation and fulfilled the eligibility criteria, was possible. This supports the hypothesis that in terms of observables the informal waged and the self-employed with low-income who are eligible in terms of the general eligibility criteria under Plan Trabajar and other workfare programs but do not have access, are similar to the program participants and can be analyzed in workfare program evaluation as control group in general. However, as the observable characteristics between the comparison, the informal sector, and the treatment group, the workfare beneficiaries, turned to out to be significantly different from each other for many of the observables, in fact they did not predict the probability of workfare participation, we cannot conclude that for the entire group of informal workers workfare and informal jobs are substitutes. It is the sub-group of the informal sector which can be matched to the workfare participants and see informal work and program participation as 
substitutable alternatives.

For this present case after making the individuals from the treated and control comparable through matching, the program impact with this control group sample is calculated and we also found that that the ATT of the program was only 20 ARG Peso per month.

In the social protection literature on Argentina, informal workers and the self-employed with low-income are a separate category of analysis when looking at protection against unemployment (Bertranou and Bonari 2005). The informal and formal distinction in terms of social security contribution is incorporated in my analysis but in addition to this informality in terms of coverage of unemployment insurance and workfare program coverage is considered. This links to the argument proposed by Levy (2008) who argues that social assistance, such as cash transfer programs, represent a subsidy to the informal workers while social protection, in terms of social security, is a tax to formal workers. He argues that these programs create incentives to stay informal instead of changing to formality.

For the incentives and design of workfare programs the results of this paper are relevant in the presence of low coverage of unemployment insurance and workfare program expansion during economic crisis. Given that some informal sector workers have similar observable characteristics to workfare participants, the low-income informal waged and the self-employed, without unemployment benefits and workfare plan access, work in order to make ends meet, as suggested by Joan Robinson's idea quoted at the beginning of this paper. Although eligible and having similar observable characteristics, access to the workfare program remains restricted to a few, often linked to political influence and clientelism (Jalan and Ravallion 1999, 2003; Narayan and Petesch 2002). For instance, in the Argentine case study of the 'Voices of the Poor' project, an interviewed day care director voices this:

"We have practically no access to Plan Trabajar; it is politically organized around fifteen neighborhoods. We managed to work for six months, but after that they pulled the plug." Narayan and Petesch 2002, pp.354 
This quote also highlights the political dimension and the geographical location of program participation, which is also reflected in the highly significant estimates of relevant geographical characteristics such as infrastructure and location in my results.

This paper looked at the before universal workfare programs at a time when the economic crisis in 2001 was ongoing and high unemployment was present in the labor market. The expansion of the workfare programs was decided after a period of political unrest, for instance road blocks, protests and the subsequent overturning of the government, which highlighted the difficult economic situation of many and the government's need to intervene in order to stabilize the country's situation.

The results of this paper give us further insights into the working of the labor market during this period: The labor market segments (the informal waged and self-employed with low income) could be possible future workfare entrants in the case of the expansion of workfare programs to the near universal program Plan Jefes. A substitution of lowpaid informal and self-employed work for program participation, if access is granted, can be expected, at least for some, and should be considered in the design of a social protection program. Lanjouw and Ravallion (1999) also argue that the composition of program participants changes as the program expands or phases out, which may be important to consider in the design of a social assistance program that responds to an economic crisis. Overall, the informal sector, even at the lower end of income, seems to be not one group, some similar to current workfare participants and others not. ${ }^{22}$ As for the debate in the literature on the composition of the informal sector and whether informal labor markets are segmented or integrated, these results even support further subdivisions or tiers in the informal sector and the sector's heterogeneity.

\footnotetext{
${ }^{22}$ For a summary on the debate of segmentation and integration see World Bank (2007). The traditional view of the Harris-Todaro model suggests segmentation of the formal and informal labor market (Harris and Todaro 1970). In this view the informal sector participants are involuntary in the informal sector. Contrary to this, Maloney (2004) supports the view of voluntary microentrepreneurs in the informal sector. Fields (1990) proposes an informal sector which is two-tiered, the lower tier being involuntary in the sector while the upper-tier being voluntary.
} 


\section{References}

Almeida, Rita and Emanuela Galasso. 2007. "Jump-Starting Self-Employment? Evidence among Welfare Participants in Argentina." IZA DP No. 2902.

Badaoui, Eliane, Eric Strobl and Frank Walsh. 2008. "Is There an Informal Employment Wage Penalty? Evidence from South Africa." Economic Development and Cultural Change, 56(3): 683-710.

Bertranou, Fabio M. and Damian Bonari. 2005. "Proteccion Social en Argentina: Financiamiento, Cobertura y Desempeno, 1990-2003." Oficina Internacional del Trabajo. Santiago.

Besley, Timothy and Stephen Coate. 1992. "Workfare versus Welfare: Incentive Arguments for Work Requirements in Poverty-Alleviation Program." American Economic Review, 82(1): 249-261.

Behncke, Stefanie, Markus Froelich and Michael Lechner. 2009. "A Caseworker Like Me - Does The Similarity Between The Unemployed And Their Caseworkers Increase Job Placements" Unpublished Working Paper.

Blundell, Richard and Monica Costa Dias. 2000."Evaluation Methods for NonExperimental Data." Fiscal Studies, 21(4): 427-468.

Caliendo, Marco and Sabine Kopenig. 2008. "Some practical guidance for the implementation of propensity score matching." Journal of Economic Surveys, 22(1): 31-72.

Coady, David, Margaret E. Grosh and John Hoddinott. 2004. Targeting of Transfers in Developing Countries. Washington D.C.: The World Bank and IFPRI.

Eisenstedt, Keith. 1998. "Public Employment Programs Case Study: Argentina's Trabajar Program." World Bank. Mimeo.

Fields, Gary S.. 1990. "Labour market modelling and the urban informal sector: theory and evidence." in The Informal Sector Revisited. David Turnham, Bernard Salomé and Antoine Schwarz ed: OECD, Paris.

Fiszbein, Ariel, Paula I. Giovagnoli and Isidro Aduriz. 2002. "Argentina's crisis and its impact on household welfare." World Bank Working Paper by the World Bank Office for Argentina, Chile, Paraguay and Uruguay, 1/02.

Galasso, Emanuela, Martin Ravallion and Agustin Salvia. 2001. "Assisting the Transition 
from Workfare to Work: A randomized experiment in Argentina." World Bank Policy Research Working Paper 2738.

Galasso, Emanuela and Martin Ravallion. 2003. "Social Protection in a Crisis: Argentina's Plan Jefes y Jefas." World Bank Policy Research Working Paper No. 3165.

Galasso, Emanuela and Martin Ravallion. 2004. "Social Protection in a Crisis: Argentina's Plan Jefes y Jefas." The World Bank Economic Review, 18(3): 367399.

Gasparini, L.C. 2002. "Microeonometric decompositions of aggregate variables: an application to labour informality in Argentina." Applied Economics, 34(18): 2257-66.

Gasparini, Leonardo, Francisco Haimovich and Sergio Oliveri. 2006. "Labor informality effects of the Programa Jefes de Hogar." Universidad Nacional de La Plata. CEDLAS. Mimeo.

Gill, Indermit S., Claudio E. Montenegro and Doerte Doemeland ed. 2002. Crafting Labor Policy: Techniques and Lessons from Latin America. Washington D.C.: The World Bank and Stanford University Press.

Giovagnoli, Paula. 2005. "Poverty Alleviation or Political Networking? A combined qual-quant analysis of the implementation of safety nets in post-crisis Argentina." DESTIN Working Paper No.05-66.

Harris, J.R. and M.P. Todaro. 1970. "Migration, Unemployment and Development: A two sector analysis." The American Economic Review, 60(1): 126-142.

Heckman, James J., Hidehiko Ichimura and Petra Todd. 1998. "Matching as an Econometric Evaluation Estimator" The Review of Economic Studies, 65(2): 261294.

Heckman, James J., Robert Lalonde and Jeffrey Smith. 1999. "The economics and econometrics of active labor market programs." In Handbook of Labor Economics. Orley Ashenfelter and David Card ed., 1865-2097. Amsterdam: North-Holland.

Iturriza, Ana, Arjun S. Bedi and Robert Sparrow. 2008. "Unemployment Assistance and Transition to Employment in Argentina." IZA Discussion Paper 3579. 
Jalan, Jyotsna and Martin Ravallion. 1999. "Income gains to the poor from workfare: estimates for Argentina's Trabajar Program." World Bank Policy Research Working Paper 2149.

Jalan, Jyotsna and Martin Ravallion. 2003. "Estimating the Benefit Incidence of an Antipoverty Program by Propensity-Score Matching." Journal of Business and Economic Statistics, 21(1): 31-42.

Khamis, Melanie. 2008. "Crisis and Recovery in Argentina: Labour market, poverty, inequality and pro-poor growth dynamics." In Poverty, Inequality and Migration in Latin America. Stephan Klasen and Felicitas Nowak-Lehmann ed.: Peter Lang Verlag. Ch.4: 125-153.

Lanjouw, Peter and Martin Ravallion. 1999. "Benefit Incidence, Public Spending Reforms and the Timing of Program Capture." The World Bank Economic Review, 13(2): 257-273.

Leuven, Edwin and Barbara Sianesi. 2003."PSMATCH2: Stata module to perform full Mahalanobis and propensity score matching, common support graphing and covariate imbalance testing."

Levy, Santiago. 2008. Good Intentions, Bad Outcomes: Social Policy, Informality and Economic Growth in Mexico. Washington D.C.: Brookings Institution Press.

Lodola, German. 2003. "Popular mobilization and geographic distributive paths: the case of Argentine Plan Trabajar." Working Paper for LACEA 2003.

Maloney, William F.. 2004. "Informality Revisited." World Development, 32(7): 11591178.

Marshall, Adriana. 2004. "Labour market policies and regulations in Argentina, Brazil and Mexico: Programmes and impacts." Employment Strategy Paper, ILO:2004/13.

Ministerio de Trabajo y Seguridad Social (MTSS). 1998. Programas de Empleo. Resolución 327/98. Créase el Programa "Trabajar III", el que se financiará con recursos provenientes del Fondo de Empleo y de préstamos internacionales. Buenos Aires, Argentina.

Ministerio de Trabajo, Empleo y Seguridad Social (MTSS). 2004. "Insercion laboral de los beneficiarios del Programa Jefes de Hogar -- PJH." Buenos Aires, Argentina. 
Ministerio de Economia y Producción. 2006. "Informe sobre los Programas de Empleo Provinciales 2004."

Mkandawire, Thandika. 2006. "Targeting and Universalism in Poverty Reduction." In Poverty in Focus: Social protection - the role of cash transfers. International Poverty Centre. United Nations Development Programme. Brasilia, Brazil: 3-5.

Modolo, Cristian. 2004. "Los peligros instituticionales del Plan Jefes y Jefas de Hogar." Novenas Jornadas 'Investigaciones en la facultad' de Ciencias Economicas y Estadistica, Universidad Nacional de Rosario.

Narayan, Deepa and Petti Petesch. 2002. Voices of the Poor: From Many Lands: The World Bank and Oxford University Press.

Paz, Jorge A. and Pablo D. Lopez Zadicoff. 2003. "El Programa Jefes de Hogar. Elegibilidad, participacion y trabajo." CEMA working paper.

Pratap, Sangeeta and Erwan Quintin. 2006. "Are labor markets segmented in developing countries? A semiparametric approach." European Economic Review, 50(8): 1817-1841.

Ravallion, Martin, Emanuela Galasso, Teodoro Lazo and Ernesto Philipp. 2001. "Do workfare participants recover quickly from retrenchment?" World Bank Policy Research Working Paper 2672.

Robinson, Joan. 1937. Essays in the theory of employment. Macmillan. London.

Ronconi, Lucas. 2002. "El Programa Trabajar." Working Paper No. 63. Centro de Estudios para el Desarrallo Institucional - Fundacion Gobierno y Sociedad.

Ronconi, Lucas and Ignacio Franceschelli. 2005. "Clientelism, workfare and the emergence of the piqueteros in Argentina." Working Paper for LACEA 2005.

Ronconi, Lucas and Juan Sanguinetti and Sandra Fachelli. 2004. "Poverty and Employability Effects of Workfare Programs in Argentina." Poverty and Economic Policy (PEP) Research Network working paper.

Ronconi, Lucas, Juan Sanguinetti, Sandra Fachelli, Virginia Casazza and Ignacio Franceschelli. 2006. "Poverty and Employability Effects of Workfare Programs in Argentina." Poverty and Economic Policy (PEP) PMMA Working Paper 2006-14.

Rosenbaum, Paul and Donald B. Rubin. 1983. "The central role of the propensity score in observational studies for causal effects." Biometrika, 70(1): 41-55. 
Rosenbaum, Paul and Donald B. Rubin. 1984. "Reducing bias in observational studies using subclassification on the propensity score." Journal of the American Statistical Association, 79(387): 516-524.

Sianesi, Barbara. 2004. "Programme evaluation - course notes." CEMMAP. IFS/UCL Economics Department. London.

Smith, Jeffrey. 2000. "A Critical Survey of Empirical Methods for Evaluating Active Labor Market Policies." Swiss Journal of Economics and Statistics, 136(3): 1-22.

Smith, Jeffrey: 2005. Lecture notes on Matching. University of Maryland Department of Economics.http://www.glue.umd.edu/ jsmithz/courses/626/ec626_lectures_match ing.pdf. Accessed $1^{\text {st }}$ September 2005.

Vodopivec, Milan. 2004. Income Support for the Unemployed: Issues and Options. Washington DC: World Bank.

Weitz-Shapiro, Rebecca. 2006. "Partisanship and Protest - The Politics of Workfare Distribution in Argentina." Latin American Research Review, Vol. 41, No. 3. University of Texas Press. Austin.

World Bank. 2006. Poverty Assessment: Informality in Argentina. World Bank Country Report.

World Bank. 2007. Informality - Exit and Exclusion. Latin American and Caribbean Studies. Washington D.C.. 


\section{Figures}

Figure 1: GDP and GDP Growth (1993-2005)

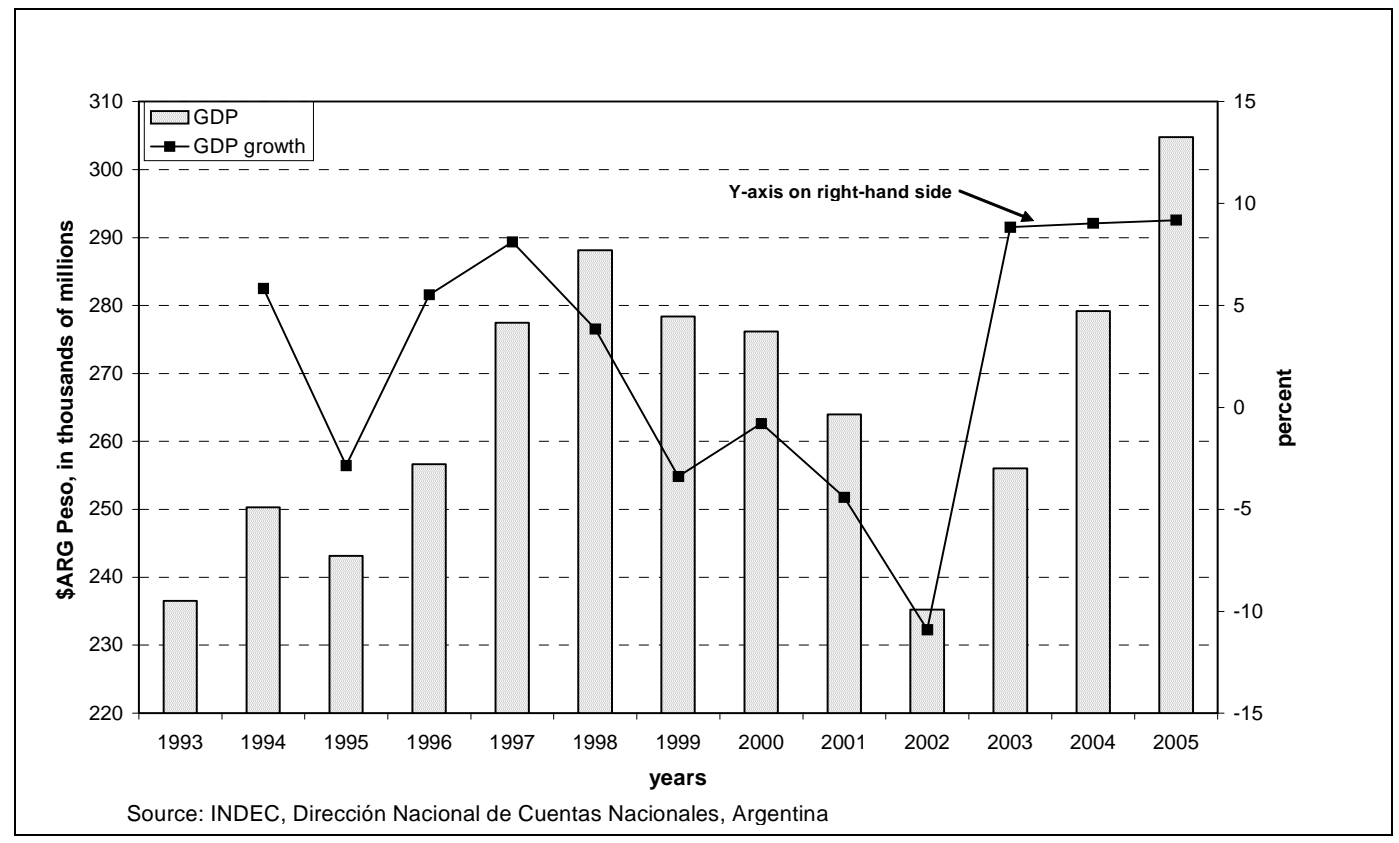

Figure 2: Common Support of Treatment and Control Group (Group 3)

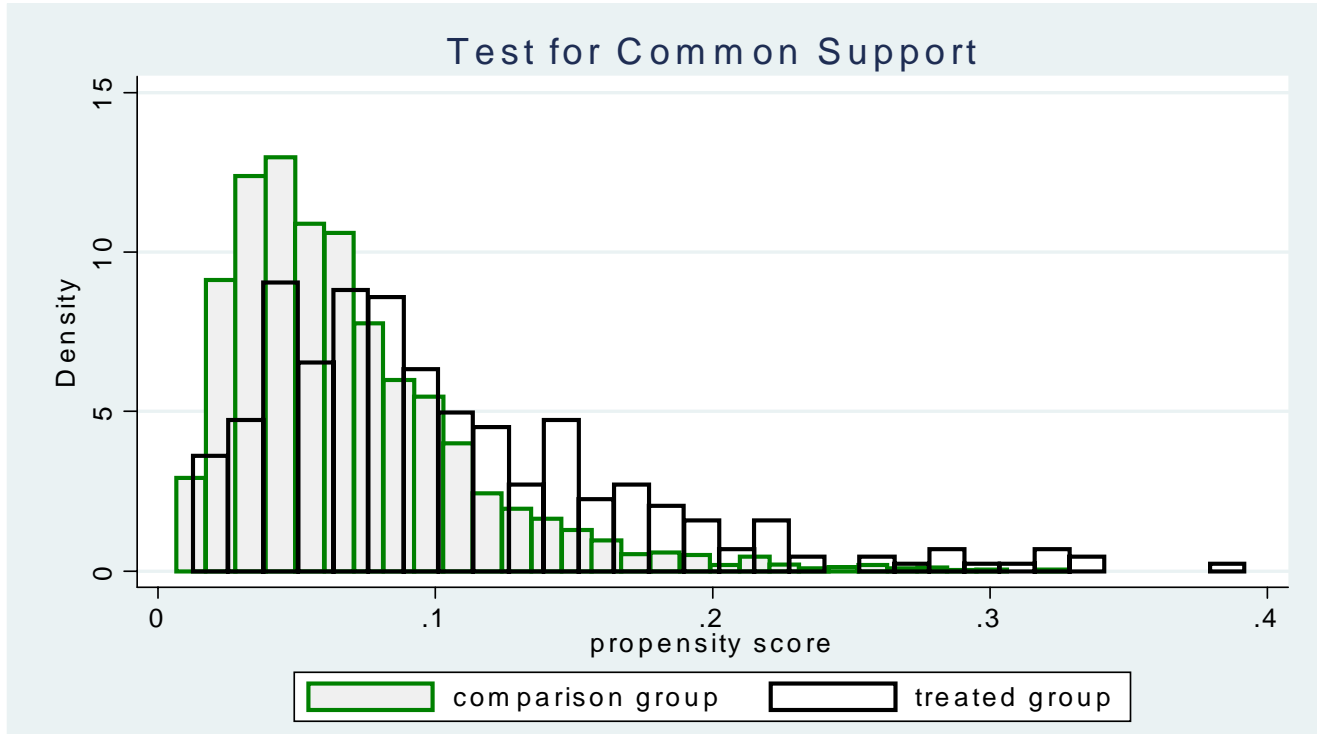

Source: own calculations based on the EPH, INDEC. 


\section{Tables}

Table 1: Unemployment Insurance Coverage, 2001 and 2002

\begin{tabular}{lcccc}
\hline \multicolumn{4}{c}{ Unemployment Insurance and the Unemployed } \\
\hline & \multicolumn{2}{c}{2001} & \multicolumn{2}{c}{2002} \\
\hline & percent & no. & percent & no. \\
\cline { 2 - 5 } Unemployed without benefit & 97.08 & 5,421 & 97.23 & 4,778 \\
Unemployed with benefit & 2.92 & 97 & 2.77 & 108 \\
Sample Size & & 5,518 & & 4,886 \\
\hline
\end{tabular}

Note: Without receiving income from unemployment insurance.

Source: own calculations based on the October waves of the EPH, INDEC.

Table 2: Comparison Groups - Different measures

\begin{tabular}{|c|c|c|c|c|c|c|}
\hline \multicolumn{7}{|c|}{ Comparison Groups, October 2001} \\
\hline & \multicolumn{2}{|c|}{ Group 1} & \multicolumn{2}{|c|}{ Group 2} & \multicolumn{2}{|c|}{ Group 3} \\
\hline & mean & stdv. & mean & stdv. & mean & stdv. \\
\hline \multicolumn{7}{|l|}{ Individual characteristics } \\
\hline Age & 38.17 & 14.20 & 35.79 & 14.70 & 37.47 & 15.28 \\
\hline Male & 0.59 & 0.49 & 0.52 & 0.50 & 0.44 & 0.50 \\
\hline Head of Household & 0.46 & 0.50 & 0.35 & 0.48 & 0.36 & 0.48 \\
\hline Spouse & 0.18 & 0.39 & 0.20 & 0.40 & 0.26 & 0.44 \\
\hline Married & 0.56 & 0.50 & 0.48 & 0.50 & 0.51 & 0.50 \\
\hline Single & 0.34 & 0.47 & 0.42 & 0.49 & 0.36 & 0.48 \\
\hline incomplete primary education & 0.10 & 0.30 & 0.12 & 0.33 & 0.16 & 0.36 \\
\hline complete primary education & 0.29 & 0.45 & 0.31 & 0.46 & 0.36 & 0.48 \\
\hline incomplete secondary education & 0.21 & 0.41 & 0.23 & 0.42 & 0.23 & 0.42 \\
\hline complete secondary education & 0.18 & 0.39 & 0.17 & 0.38 & 0.12 & 0.33 \\
\hline incomplete tertiary education & 0.12 & 0.32 & 0.12 & 0.32 & 0.09 & 0.29 \\
\hline complete tertiary education & 0.10 & 0.30 & 0.05 & 0.22 & 0.04 & 0.20 \\
\hline \multicolumn{7}{|l|}{ Household characteristics } \\
\hline No. of primary hhs.members & 4.41 & 2.27 & 4.69 & 2.41 & 4.79 & 2.53 \\
\hline Hhs. with secondary members & 0.03 & 0.17 & 0.02 & 0.15 & 0.03 & 0.16 \\
\hline No. of Children in hhs. & 1.22 & 1.55 & 1.33 & 1.68 & 1.49 & 1.80 \\
\hline House ownership & 0.72 & 0.45 & 0.72 & 0.45 & 0.70 & 0.46 \\
\hline Living arrangement - unstable & 0.03 & 0.18 & 0.04 & 0.19 & 0.04 & 0.21 \\
\hline House materials - unstable & 0.02 & 0.13 & 0.02 & 0.15 & 0.03 & 0.16 \\
\hline Water & 0.98 & 0.12 & 0.98 & 0.14 & 0.98 & 0.16 \\
\hline Bathroom - sanitary & 0.84 & 0.37 & 0.78 & 0.42 & 0.73 & 0.44 \\
\hline Sewerage & 0.53 & 0.50 & 0.44 & 0.50 & 0.40 & 0.49 \\
\hline Electricity & 1.00 & 0.07 & 0.99 & 0.09 & 0.99 & 0.10 \\
\hline \multicolumn{7}{|l|}{ Region } \\
\hline GBA & 0.56 & 0.50 & 0.55 & 0.50 & 0.53 & 0.50 \\
\hline Pampeana & 0.23 & 0.42 & 0.22 & 0.41 & 0.19 & 0.39 \\
\hline Cuyo & 0.06 & 0.24 & 0.06 & 0.24 & 0.07 & 0.26 \\
\hline NOA & 0.09 & 0.28 & 0.10 & 0.30 & 0.12 & 0.33 \\
\hline Patagonia & 0.02 & 0.14 & 0.02 & 0.13 & 0.02 & 0.13 \\
\hline NEA & 0.04 & 0.20 & 0.05 & 0.22 & 0.07 & 0.25 \\
\hline Sample Size & \multicolumn{2}{|c|}{19,586} & \multicolumn{2}{|c|}{9,713} & \multicolumn{2}{|c|}{4,710} \\
\hline Population & \multicolumn{2}{|c|}{$6,169,217$} & \multicolumn{2}{|c|}{$2,997,719$} & \multicolumn{2}{|c|}{$1,342,638$} \\
\hline
\end{tabular}

Note: Without workfare participants. Above 16 years.

1/ Group 1: Labour force:

Unemployed (no benefit income) and not formal work (informal and self-employed)

2/ Group 2: Labour force:

Unemployed (no benefit income) and not formal work (informal and self-employed).

Below or at minimum wage ARG \$200. Coherent responses for income only.

3/ Group 3: Informal workers and self-employed.

Below or at minimum wage ARG \$200. Coherent responses for income only.

Source: own calculations based on the EPH, INDEC. 
Table 3: Estimation of the propensity score (Group 3)

\begin{tabular}{|c|c|c|c|}
\hline \multicolumn{4}{|c|}{ Estimation of the propensity score } \\
\hline & Probit & Probit, 150 replics & Marginal effects \\
\hline \multirow[t]{2}{*}{ Age } & $-0.009^{\star \star \star}$ & $-0.009^{\star \star \star}$ & $-0.001^{\star \star \star}$ \\
\hline & [3.46] & [3.64] & [3.46] \\
\hline \multirow[t]{2}{*}{ Male } & $-0.242^{\star \star \star}$ & $-0.242^{\star \star \star}$ & $-0.029 * \star \star$ \\
\hline & [3.87] & [3.60] & [3.87] \\
\hline \multirow[t]{2}{*}{ Head of Household } & 0.073 & 0.073 & 0.009 \\
\hline & [0.97] & [0.97] & [0.97] \\
\hline \multirow[t]{2}{*}{ Married } & 0.086 & 0.086 & 0.01 \\
\hline & [1.42] & [1.46] & [1.42] \\
\hline \multirow[t]{2}{*}{ incomplete secondary education } & -0.064 & -0.064 & -0.007 \\
\hline & {$[0.88]$} & [0.94] & [0.88] \\
\hline \multirow[t]{2}{*}{ complete secondary education } & -0.054 & -0.054 & -0.006 \\
\hline & {$[0.59]$} & {$[0.60]$} & {$[0.59]$} \\
\hline \multirow[t]{2}{*}{ incomplete tertiary education } & -0.101 & -0.101 & -0.011 \\
\hline & {$[0.86]$} & [0.91] & {$[0.86]$} \\
\hline \multirow[t]{2}{*}{ complete tertiary education } & -0.239 & -0.239 & -0.024 \\
\hline & {$[1.28]$} & [1.23] & [1.28] \\
\hline \multirow[t]{2}{*}{ No.of primary household members } & $0.025^{\star}$ & $0.025^{\star}$ & $0.003^{*}$ \\
\hline & [1.87] & {$[1.84]$} & [1.87] \\
\hline \multirow[t]{2}{*}{ No. of children in hhs. } & 0.031 & $0.031 *$ & 0.004 \\
\hline & [1.63] & {$[1.79]$} & [1.63] \\
\hline \multirow[t]{2}{*}{ living arrangement - unstable } & 0.144 & 0.144 & 0.019 \\
\hline & {$[1.25]$} & {$[1.50]$} & {$[1.25]$} \\
\hline \multirow[t]{2}{*}{ infrastructure problems/villa miseria } & $0.225^{\star \star \star}$ & $0.225^{\star \star \star}$ & $0.027^{\star \star \star}$ \\
\hline & [3.59] & [3.62] & [3.59] \\
\hline \multirow[t]{2}{*}{ Pampeana } & $0.198^{\star \star}$ & $0.198^{\star \star}$ & $0.026^{\star \star}$ \\
\hline & [2.13] & [2.21] & [2.13] \\
\hline \multirow[t]{2}{*}{ Cuyo } & -0.124 & -0.124 & -0.014 \\
\hline & {$[1.02]$} & [1.03] & {$[1.02]$} \\
\hline \multirow[t]{2}{*}{ NOA } & 0.024 & 0.024 & 0.003 \\
\hline & [0.25] & {$[0.24]$} & [0.25] \\
\hline \multirow[t]{2}{*}{ Patagonia } & $0.669 * \star \star$ & $0.669 * \star \star$ & $0.122^{\star \star \star}$ \\
\hline & {$[5.79]$} & {$[5.72]$} & {$[5.79]$} \\
\hline \multirow[t]{2}{*}{ NEA } & $-0.195^{\star}$ & $-0.195^{\star}$ & $-0.021^{\star}$ \\
\hline & {$[1.74]$} & [1.82] & {$[1.74]$} \\
\hline \multirow[t]{2}{*}{ constant } & $-1.487^{\star \star \star}$ & $-1.487^{\star \star \star}$ & \\
\hline & [9.34] & [9.83] & \\
\hline Observations & 4961 & 4961 & 4961 \\
\hline pseudo R-squared & 0.056 & 0.056 & 0.056 \\
\hline Absolute value of $z$ statistics in brackets & & & \\
\hline * significant at $10 \%$; ** significant at $5 \%$; ** & nt at $1 \%$ & & \\
\hline & 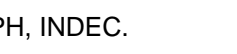 & & \\
\hline
\end{tabular}


Table 4: Matching on and off common support (Group 3)

\begin{tabular}{c|c|c|c}
\hline \multicolumn{4}{c}{ Matching and Common Support } \\
\hline $\begin{array}{c}\text { From Matching: } \\
\text { treatment assignment }\end{array}$ & $\begin{array}{r}\text { From Matching: } \\
\text { common support }\end{array}$ & \\
\hline off support & on support & Total \\
\hline treated & 0 & 4,611 & 4,611 \\
Total & 5 & 345 & 350 \\
\hline
\end{tabular}

Source: own estimations based on the October EPH, INDEC.

Table 5: Program impact (Group 3)

\begin{tabular}{lcccccc}
\hline \multicolumn{7}{c}{ Outcome variable: Average treatment on treated } \\
\hline Variable & Sample & Treated & Controls & Difference & S.E. & T-stat \\
\hline \multirow{2}{*}{ income } & \multirow{2}{*}{ ATT } & \multirow{2}{*}{139.64} & \multirow{2}{*}{119.55} & $20.08^{\star \star \star}$ & 6.56 & 3.06 \\
& & & & & $\mathbf{6 . 9 3}$ & $\mathbf{2 . 9 0}$ \\
\hline
\end{tabular}

Note: In bold standard error and t-statistics are based on 150 bootstraps.

* significant at $10 \%$; ** significant at $5 \%$; *** significant at $1 \%$, based on bootstrapped s.e..

ATT: Average Treatment Effect on the Treated.

Source: own estimations based on the October EPH, INDEC. 
Table 6: Assessment of matching quality (Group 3)

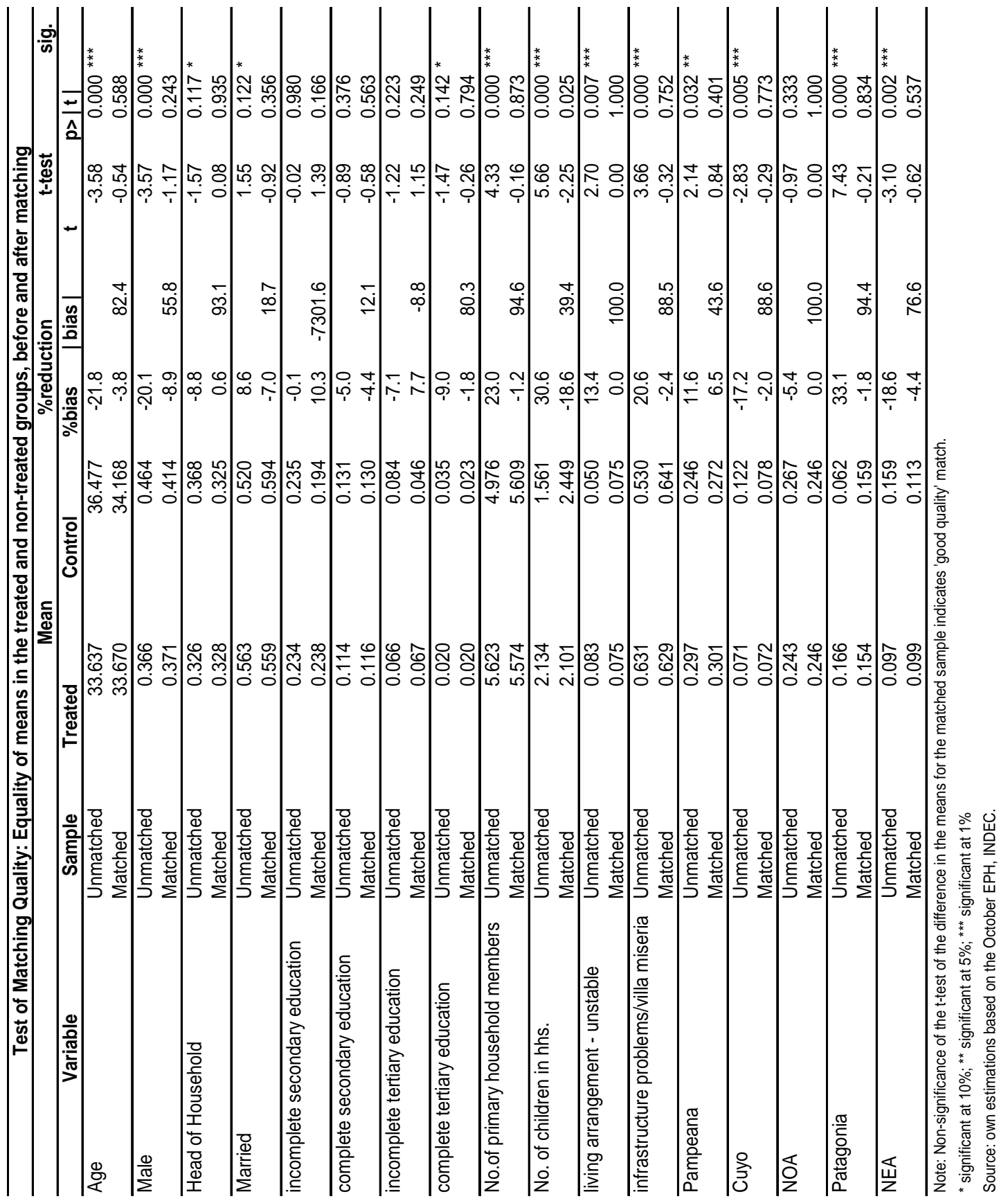




\section{Annex: Descriptive Statistics, Additional Figures and Tables}

Figures

Figure A.1: Common Support of Treatment and Control Group (Group 1)

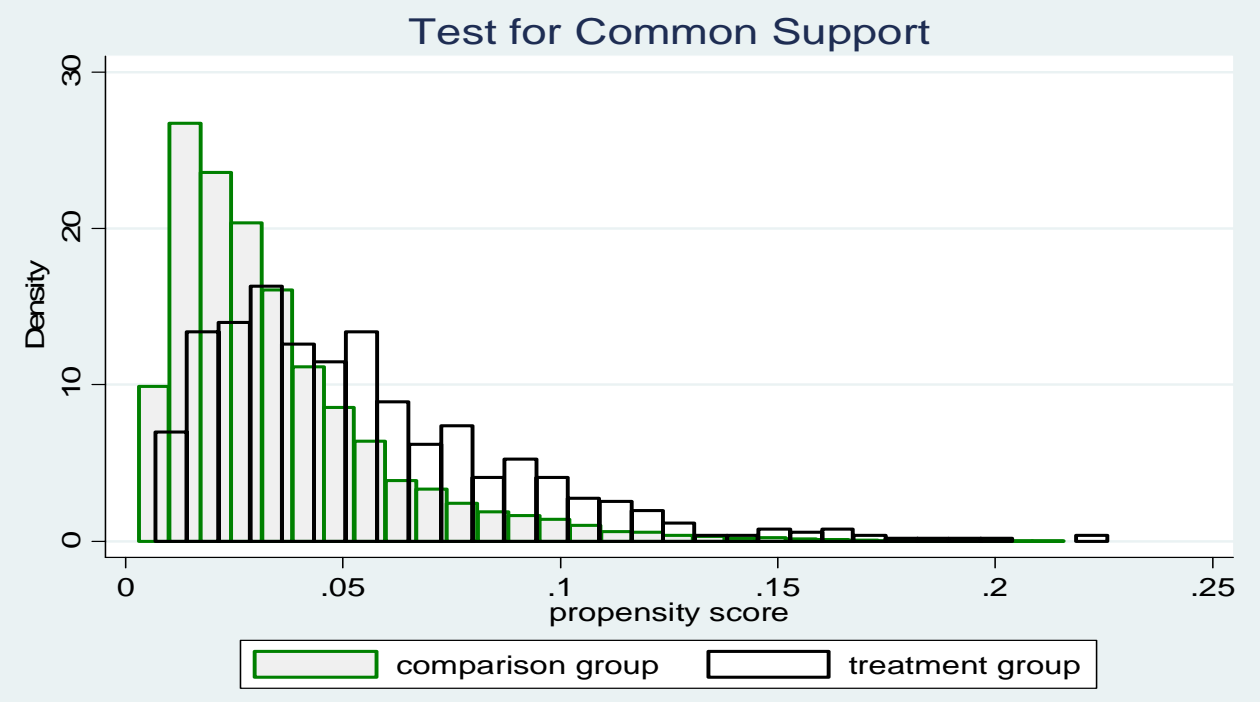

Source: own calculations based on the EPH, INDEC.

Figure 5.A.2: Common Support of Treatment and Control Group - Group 2 (Labor force participants with below or at minimum wage earnings)

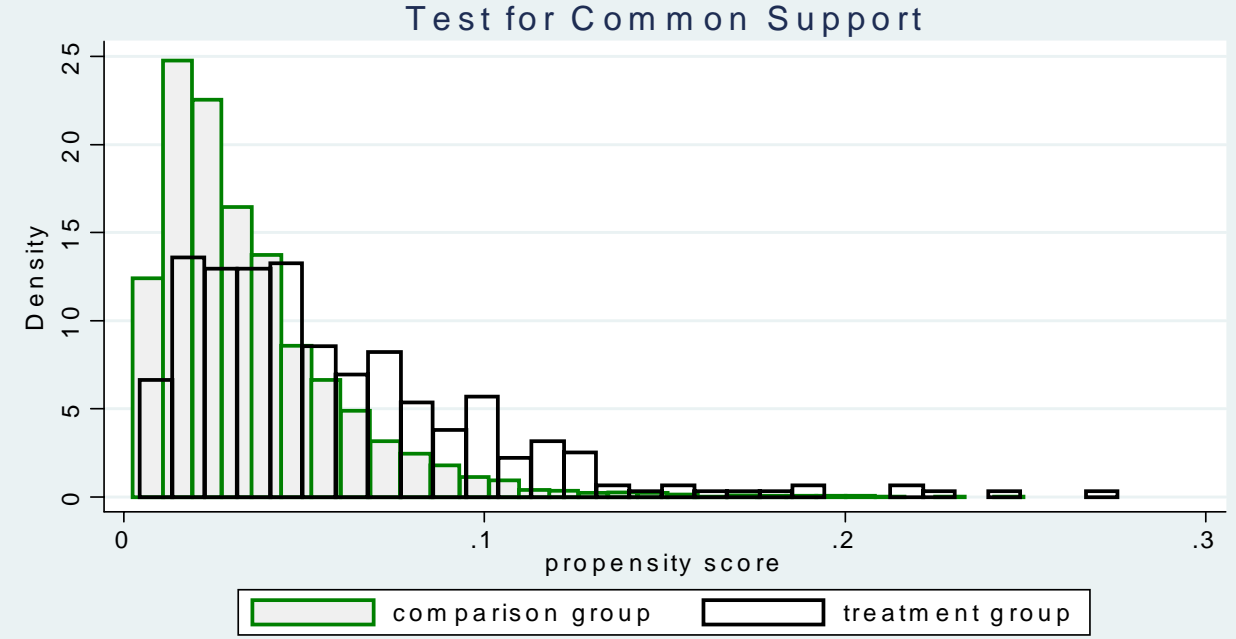

Source: own calculations based on the EPH, INDEC. 


\section{Tables: Descriptive Statistics}

\section{Table A.1: Summary Statistics}

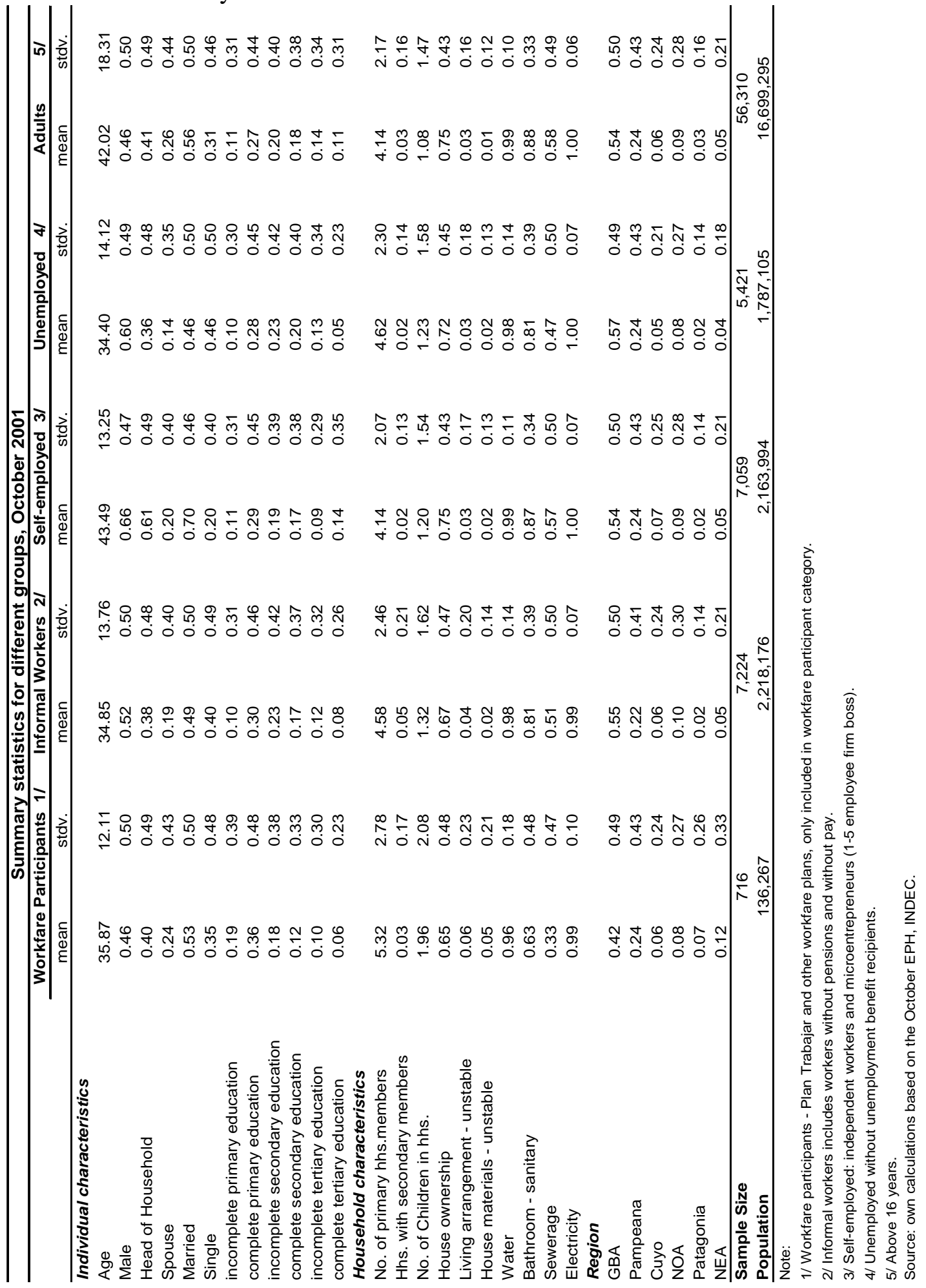


Table A.2: Summary Statistics - Group 1 (Labor force participants)

\begin{tabular}{lrrrrr}
\hline & Matching Sample 1 & & \\
\hline Variable & Obs & Mean & Std. Dev. & Min & Max \\
\hline Age & 20296 & 37.20526 & 13.75308 & 13 & 98 \\
Male & 20302 & 0.596838 & 0.490545 & 0 & 1 \\
Head of Household & 20302 & 0.461186 & 0.498504 & 0 & 1 \\
Married & 20300 & 0.563202 & 0.496002 & 0 & 1 \\
incomplete secondary education & 20290 & 0.225579 & 0.417973 & 0 & 1 \\
complete secondary education & 20290 & 0.180877 & 0.384926 & 0 & 1 \\
incomplete tertiary education & 20290 & 0.104682 & 0.306151 & 0 & 1 \\
complete tertiary education & 20290 & 0.084081 & 0.277516 & 0 & 1 \\
No.of primary household members & 20008 & 4.602109 & 2.422007 & 1 & 22 \\
No.of children in hhs. & 20302 & 1.325387 & 1.612969 & 0 & 11 \\
living arrangements - unstable & 20298 & 0.036752 & 0.188158 & 0 & 1 \\
infrastructure problems/villa miseria & 20302 & 0.436558 & 0.495971 & 0 & 1 \\
Pampeana & 20302 & 0.312482 & 0.463516 & 0 & 1 \\
Cuyo & 20302 & 0.105507 & 0.307213 & 0 & 1 \\
NOA & 20302 & 0.212688 & 0.409219 & 0 & 1 \\
Patagonia & 20302 & 0.092553 & 0.289811 & 0 & 1 \\
NEA & 20302 & 0.116688 & 0.321056 & 0 & 1 \\
\hline
\end{tabular}

Base: GBA, Single, Primary education.

Note: infrastructure problems/villa miseria dummy indicates whether household has access to sewerage,

electricity, a sanitary bathroom, water and stable built housing or not.

Source: own calculations based on the EPH, INDEC.

Table A.3: Summary Statistics - Group 2 (Labor force participants with below or at minimum wage earnings)

\begin{tabular}{lrrrrr}
\hline & Matching Sample 2 & & & \\
\hline Variable & Obs & Mean & Std. Dev. & Min & Max \\
\hline Age & 10068 & 34.79996 & 13.91601 & 17 & 98 \\
Male & 10070 & 0.519861 & 0.49963 & 0 & 1 \\
Head of Household & 10070 & 0.350646 & 0.477196 & 0 & 1 \\
Married & 10068 & 0.477553 & 0.499521 & 0 & 1 \\
incomplete secondary education & 10069 & 0.24054 & 0.427433 & 0 & 1 \\
complete secondary education & 10069 & 0.164565 & 0.370806 & 0 & 1 \\
incomplete tertiary education & 10069 & 0.104082 & 0.305382 & 0 & 1 \\
complete tertiary education & 10069 & 0.042507 & 0.201752 & 0 & 1 \\
No.of primary household members & 9934 & 4.927924 & 2.602038 & 1 & 22 \\
No.of children in hhs. & 10070 & 1.441708 & 1.730223 & 0 & 11 \\
living arrangements - unstable & 10067 & 0.044204 & 0.205558 & 0 & 1 \\
infrastructure problems/villa miseria & 10070 & 0.504171 & 0.500007 & 0 & 1 \\
Pampeana & 10070 & 0.293645 & 0.455454 & 0 & 1 \\
Cuyo & 10070 & 0.105065 & 0.306652 & 0 & 1 \\
NOA & 10070 & 0.238828 & 0.426389 & 0 & 1 \\
Patagonia & 10070 & 0.076266 & 0.265437 & 0 & 1 \\
NEA & 10070 & 0.126912 & 0.332891 & 0 & 1 \\
\hline
\end{tabular}

Base: GBA, Single, Primary education.

Note: infrastructure problems/villa miseria dummy indicates whether household has access to sewerage,

electricity, a sanitary bathroom, water and stable built housing or not.

Source: own calculations based on the EPH, INDEC. 
Table A.4: Summary Statistics - Group 3 (Informal workers and self-employed with below or at minimum wage earnings)

\begin{tabular}{|c|c|c|c|c|c|c|}
\hline \multicolumn{7}{|c|}{ Matching Sample 3} \\
\hline Variable & Obs & Mean & Std. Dev. & Min & & \\
\hline Age & 5066 & 36.17548 & 14.36488 & & 17 & 98 \\
\hline Male & 5067 & 0.452141 & 0.497753 & & 0 & 1 \\
\hline Head of Household & 5067 & 0.357608 & 0.479343 & & 0 & 1 \\
\hline Married & 5065 & 0.513722 & 0.499861 & & 0 & \\
\hline incomplete secondary education & 5066 & 0.231938 & 0.422112 & & 0 & 1 \\
\hline complete secondary education & 5066 & 0.129688 & 0.335993 & & 0 & 1 \\
\hline incomplete tertiary education & 5066 & 0.087446 & 0.282515 & & 0 & 1 \\
\hline complete tertiary education & 5066 & 0.033952 & 0.181123 & & 0 & 1 \\
\hline No.of primary household members & 4965 & 5.018933 & 2.701293 & & 1 & 22 \\
\hline No.of children in hhs. & 5067 & 1.580028 & 1.82583 & & 0 & 11 \\
\hline living arrangements - unstable & 5065 & 0.051925 & 0.221898 & & 0 & 1 \\
\hline infrastructure problems/villa miseria & 5067 & 0.533057 & 0.498955 & & 0 & 1 \\
\hline Pampeana & 5067 & 0.250641 & 0.433425 & & 0 & 1 \\
\hline Cuyo & 5067 & 0.1194 & 0.324291 & & 0 & 1 \\
\hline NOA & 5067 & 0.26564 & 0.441717 & & 0 & 1 \\
\hline Patagonia & 5067 & 0.068877 & 0.25327 & & 0 & 1 \\
\hline NEA & 5067 & 0.154529 & 0.361491 & & 0 & 1 \\
\hline
\end{tabular}

Base: GBA, Single, Primary education.

Note: infrastructure problems/villa miseria dummy indicates whether household has access to sewerage, electricity, a sanitary bathroom, water and stable built housing or not.

Source: own calculations based on the EPH, INDEC. 
Tables: Further results for the comparison groups

Table A.5: Estimation of the Propensity Score (Group 1)

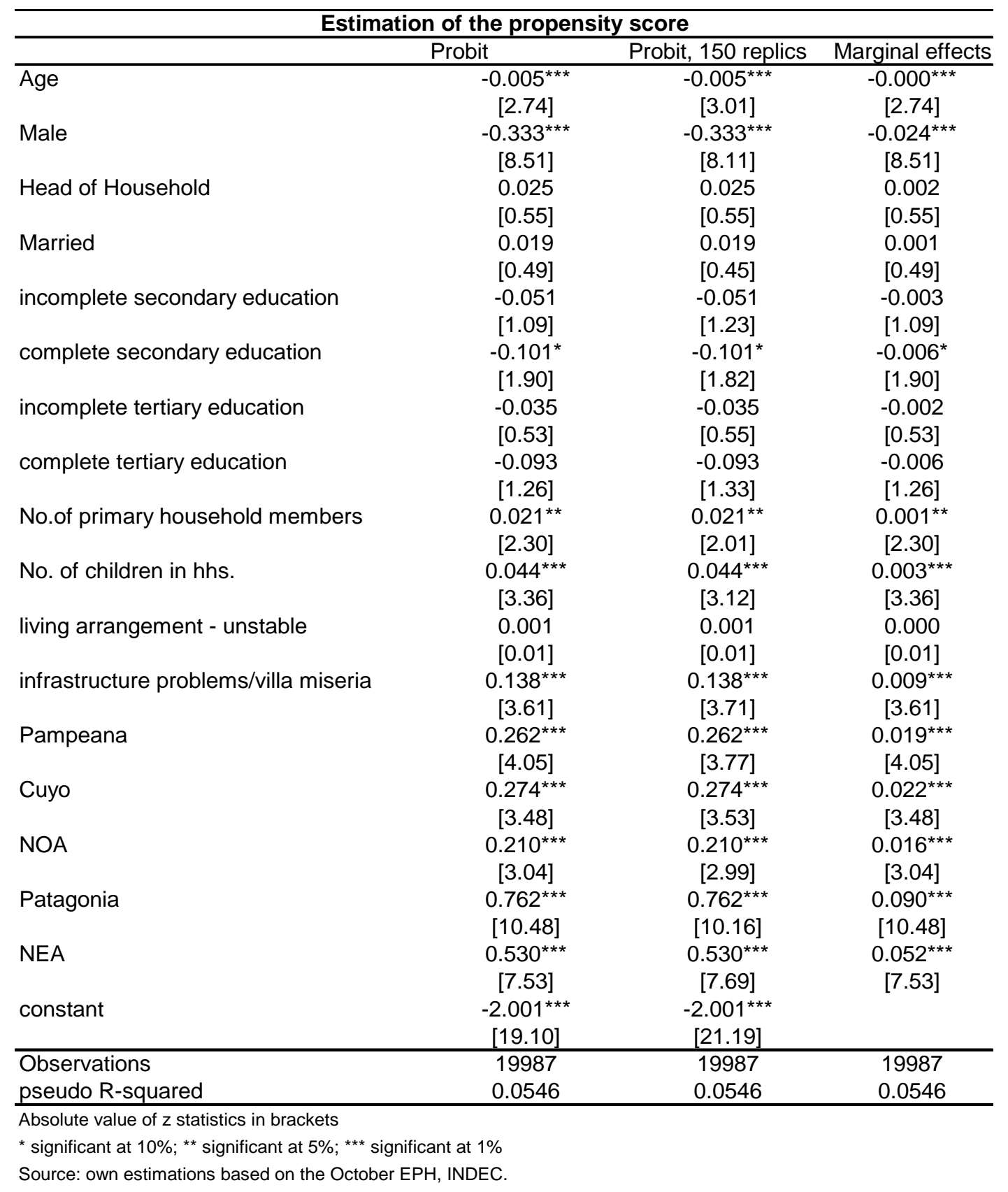


Table A.6: Matching on and off common support (Group 1)

\begin{tabular}{c|c|c|c}
\hline \multicolumn{4}{c}{ Matching and Common Support } \\
\hline $\begin{array}{c}\text { From Matching: } \\
\text { treatment assignment }\end{array}$ & $\begin{array}{c}\text { From Matching: } \\
\text { common support }\end{array}$ & \\
\hline off support & on support & Total \\
\hline treated & 0 & 19,282 & 19,282 \\
Total & 2 & 703 & 705 \\
\hline
\end{tabular}

Source: own estimations based on the October EPH, INDEC.

Table A.7: Program impact (Group 1)

\begin{tabular}{lcccccc}
\hline \multicolumn{7}{c}{ Outcome variable: Average treatment on treated } \\
\hline Variable & Sample & Treated & Controls & Difference & S.E. & T-stat \\
\hline \multirow{2}{*}{ income } & \multirow{2}{*}{ ATT } & 269.24 & 233.79 & $35.45^{\star}$ & 18.66 & 1.90 \\
& & & & & $\mathbf{2 3 . 3 6}$ & $\mathbf{1 . 5 2}$ \\
\hline
\end{tabular}

Note: In bold standard error and t-statistics are based on 150 bootstraps.

* significant at $10 \%$; ${ }^{* *}$ significant at $5 \%$; ${ }^{* * *}$ significant at $1 \%$, based on bootstrapped s.e.. ATT: Average Treatment Effect on the Treated.

Source: own estimations based on the October EPH, INDEC. 
Table A.8: Assessment of matching quality (Group 1)

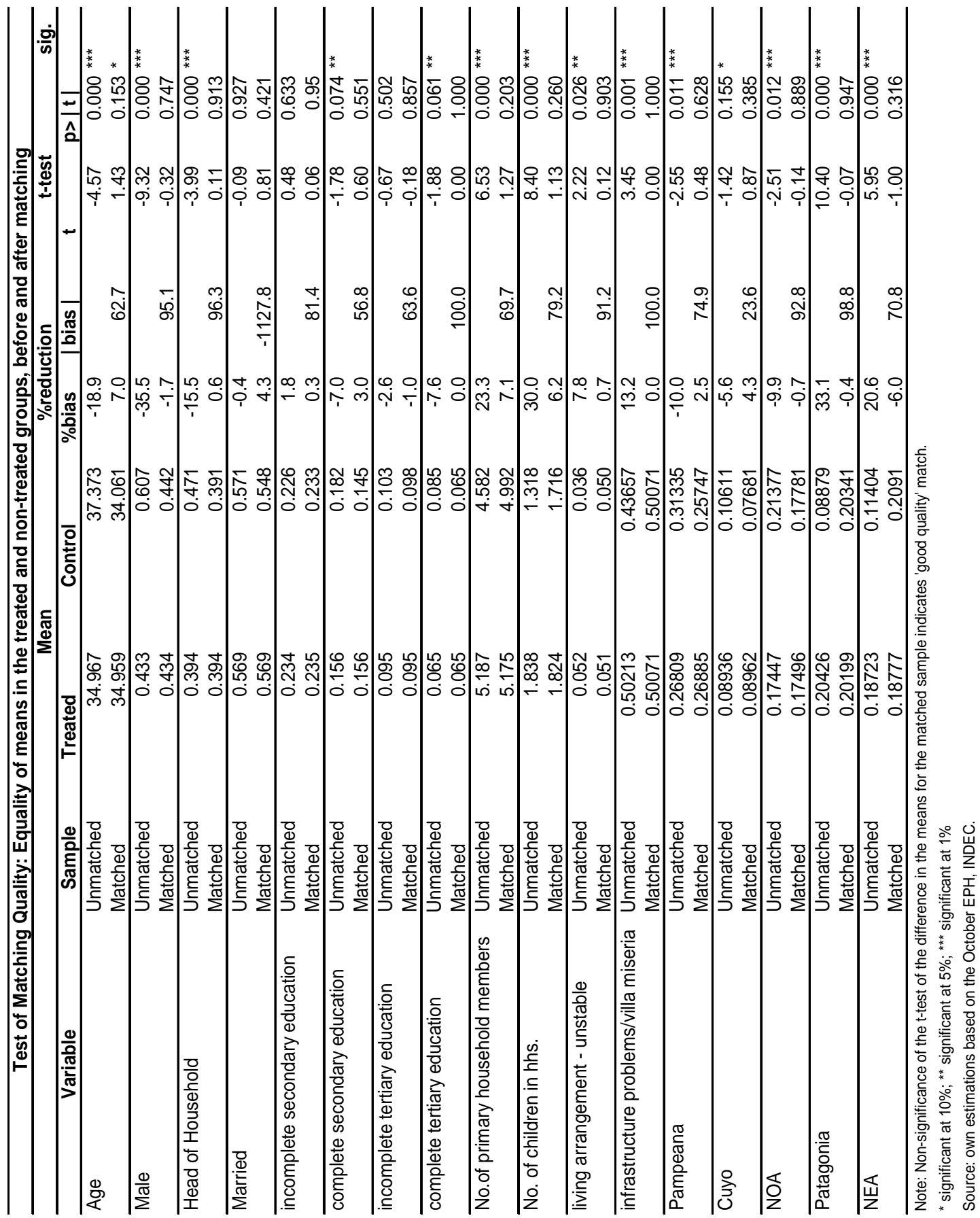


Table A.9: Summary of the distribution of the absolute bias (Group 1)

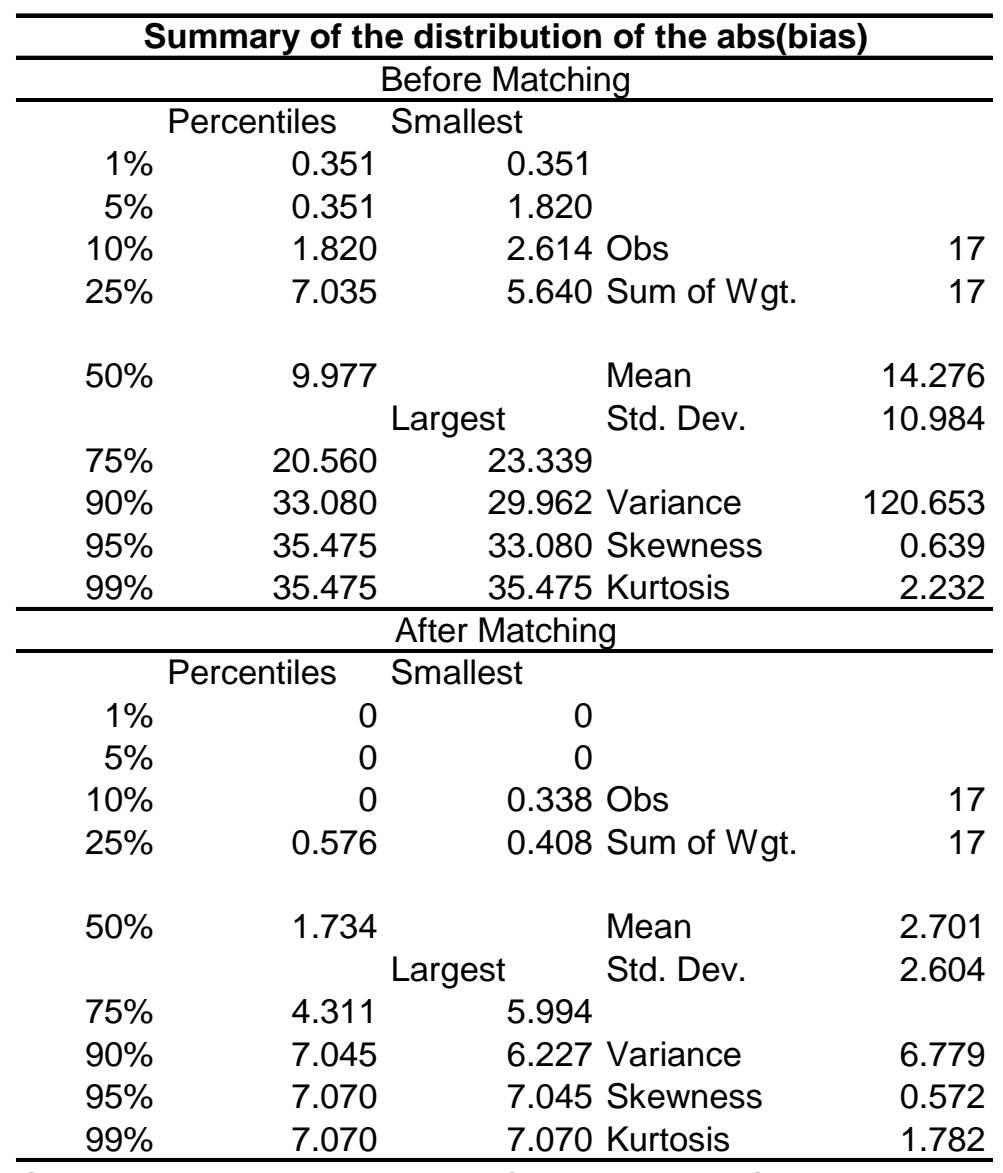

Source: own estimations based on the October EPH, INDEC. 
Table A.10: Estimation of the Propensity Score (Group 2)

\begin{tabular}{|c|c|c|c|}
\hline \multicolumn{4}{|c|}{ Estimation of the propensity score } \\
\hline & Probit & Probit, 150 replics & Marginal effects \\
\hline \multirow[t]{2}{*}{ Age } & $-0.005^{\star \star}$ & $-0.005^{\star \star}$ & $-0.000^{\star *}$ \\
\hline & [2.13] & [2.11] & [2.13] \\
\hline \multirow[t]{2}{*}{ Male } & $-0.345^{\star \star \star}$ & $-0.345^{\star \star *}$ & $-0.023^{\star \star \star}$ \\
\hline & {$[6.27]$} & {$[6.21]$} & [6.27] \\
\hline \multirow[t]{2}{*}{ Head of Household } & 0.039 & 0.039 & 0.003 \\
\hline & {$[0.59]$} & {$[0.58]$} & {$[0.59]$} \\
\hline \multirow[t]{2}{*}{ Married } & $0.110^{* \star}$ & $0.110^{* *}$ & $0.007^{\star *}$ \\
\hline & [2.02] & [2.34] & [2.02] \\
\hline \multirow[t]{2}{*}{ incomplete secondary education } & $-0.127^{\star \star}$ & $-0.127^{\star \star}$ & $-0.008^{* *}$ \\
\hline & {$[1.97]$} & [2.09] & [1.97] \\
\hline \multirow[t]{2}{*}{ complete secondary education } & $-0.232^{\star \star \star}$ & $-0.232^{\star \star \star}$ & $-0.013^{\star \star \star}$ \\
\hline & [2.89] & [2.84] & [2.89] \\
\hline \multirow[t]{2}{*}{ incomplete tertiary education } & $-0.208^{\star *}$ & $-0.208^{\star}$ & $-0.012^{\star \star}$ \\
\hline & [2.03] & [1.92] & [2.03] \\
\hline \multirow[t]{2}{*}{ complete tertiary education } & $-0.368^{\star *}$ & $-0.368^{\star *}$ & $-0.018^{\star *}$ \\
\hline & {$[2.26]$} & [2.04] & {$[2.26]$} \\
\hline \multirow[t]{2}{*}{ No.of primary household members } & 0.018 & 0.018 & 0.001 \\
\hline & {$[1.54]$} & {$[1.55]$} & {$[1.54]$} \\
\hline \multirow[t]{2}{*}{ No. of children in hhs. } & $0.047^{\star \star \star}$ & $0.047^{* *}$ & $0.003^{\star \star \star}$ \\
\hline & [2.70] & [2.53] & [2.70] \\
\hline \multirow[t]{2}{*}{ living arrangement - unstable } & $0.170^{\star}$ & 0.170 & $0.013^{*}$ \\
\hline & [1.65] & [1.57] & [1.65] \\
\hline \multirow[t]{2}{*}{ infrastructure problems/villa miseria } & $0.204^{\star \star \star}$ & $0.204^{\star \star \star}$ & $0.013^{\star \star \star}$ \\
\hline & {$[3.71]$} & [3.66] & [3.71] \\
\hline \multirow[t]{2}{*}{ Pampeana } & 0.131 & $0.131^{*}$ & 0.009 \\
\hline & [1.62] & {$[1.70]$} & [1.62] \\
\hline \multirow[t]{2}{*}{ Cuyo } & -0.018 & -0.018 & -0.001 \\
\hline & {$[0.17]$} & {$[0.16]$} & {$[0.17]$} \\
\hline \multirow[t]{2}{*}{$\mathrm{NOA}$} & 0.125 & $0.125^{\star}$ & 0.009 \\
\hline & [1.49] & [1.67] & [1.49] \\
\hline \multirow[t]{2}{*}{ Patagonia } & $0.558^{\star \star \star}$ & $0.558^{\star \star \star}$ & $0.057^{\star \star \star}$ \\
\hline & [5.61] & {$[6.17]$} & [5.61] \\
\hline \multirow[t]{2}{*}{ NEA } & -0.051 & -0.051 & -0.003 \\
\hline & {$[0.50]$} & {$[0.55]$} & {$[0.50]$} \\
\hline \multirow[t]{2}{*}{ constant } & $-1.868^{* \star *}$ & $-1.868^{\star \star \star}$ & \\
\hline & [13.10] & {$[13.74]$} & \\
\hline \multirow{2}{*}{$\begin{array}{l}\text { Observations } \\
\text { pseudo R-squared }\end{array}$} & 9928 & 9928 & 9928 \\
\hline & 0.058 & 0.058 & 0.058 \\
\hline \multicolumn{4}{|c|}{ Absolute value of $z$ statistics in brackets } \\
\hline \multicolumn{4}{|c|}{ * significant at $10 \%$; ** significant at $5 \%$; ${ }^{* *}$ significant at $1 \%$} \\
\hline \multicolumn{4}{|c|}{ Source: own estimations based on the October EPH, INDEC. } \\
\hline
\end{tabular}


Table A.11: Matching on and off common support (Group 2)

\begin{tabular}{|c|c|c|c|}
\hline \multicolumn{4}{|c|}{ Matching and Common Support } \\
\hline From Matching: & $\begin{array}{r}\text { From Matc } \\
\text { comn }\end{array}$ & $\begin{array}{l}\text { g: } \\
\text { n support }\end{array}$ & \\
\hline treatment assignment & off support & on support & Total \\
\hline untreated & 0 & 9,578 & 9,578 \\
\hline treated & 1 & 349 & 350 \\
\hline Total & 1 & 9,927 & 9,928 \\
\hline
\end{tabular}

Source: own estimations based on the October EPH, INDEC.

Table A.12: Program impact (Group 2)

\begin{tabular}{lllllll}
\hline \multicolumn{7}{c}{ Outcome variable: Average treatment on treated } \\
\hline Variable & Sample & Treated & Controls & Difference & S.E. & T-stat \\
\hline \multirow{2}{*}{ income } & \multirow{2}{*}{ ATT } & \multirow{2}{*}{139.90} & 71.92 & $67.98^{\star \star \star}$ & 5.97 & 11.40 \\
& & & & & $\mathbf{8 . 7 7}$ & $\mathbf{7 . 7 5}$ \\
\hline
\end{tabular}

Note: In bold standard error and t-statistics are based on 150 bootstraps.

* significant at $10 \%$; ** significant at $5 \%$; *** significant at $1 \%$, based on bootstrapped s.e..

ATT: Average Treatment Effect on the Treated.

Source: own estimations based on the October EPH, INDEC. 
Table A.13: Assessment of matching quality (Group 2)

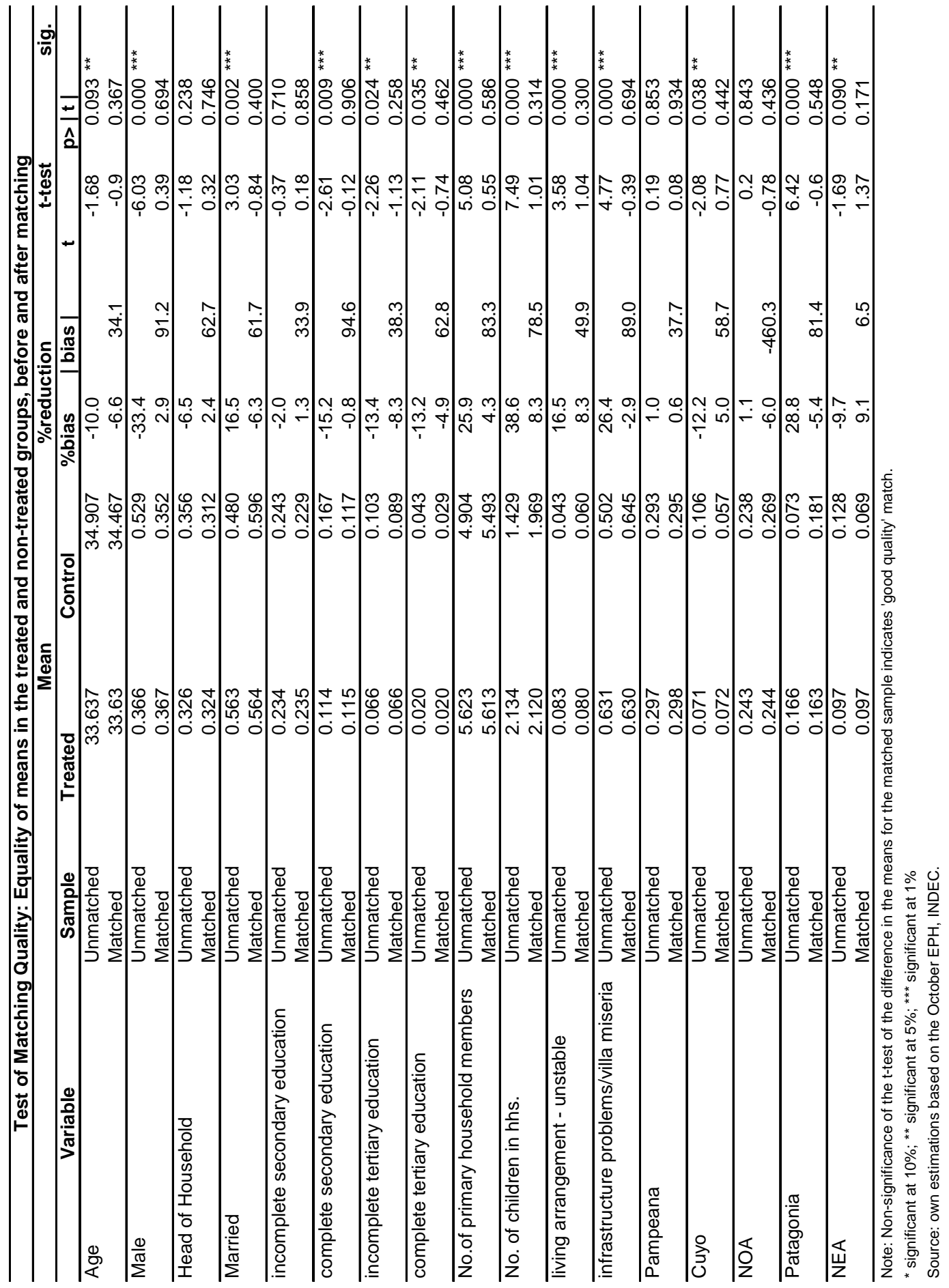


Table A.14: Summary of the distribution of the absolute bias (Group 2)

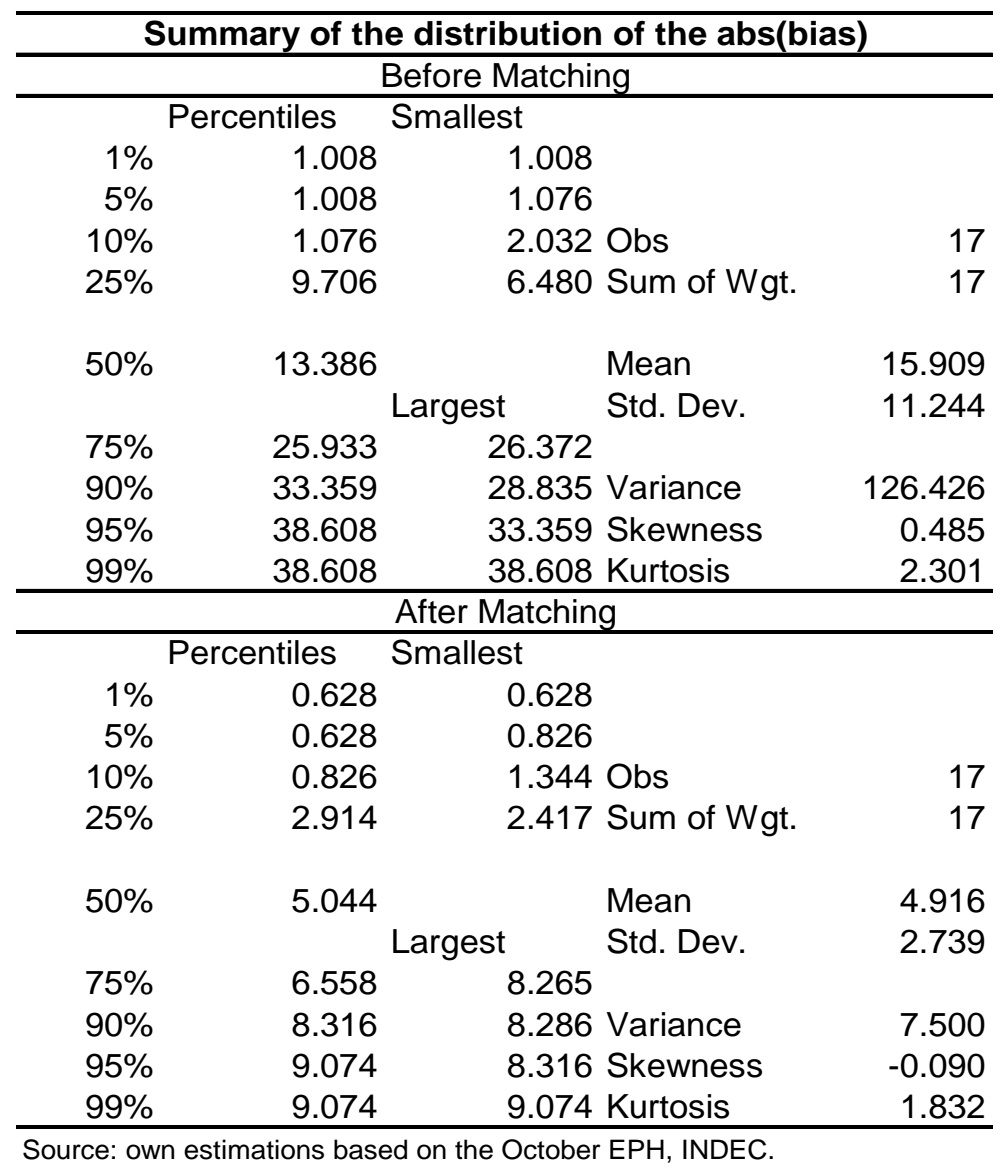


Table A.15: Summary of the distribution of the absolute bias (Group 3)

\begin{tabular}{|c|c|c|c|c|}
\hline \multicolumn{5}{|c|}{ Summary of the distribution of the abs(bias) } \\
\hline \multicolumn{5}{|c|}{ Before Matching } \\
\hline \multicolumn{2}{|c|}{ Percentiles } & \multicolumn{2}{|c|}{ Smallest } & \\
\hline $1 \%$ & 0.139 & \multicolumn{2}{|c|}{0.139} & \\
\hline $5 \%$ & 0.139 & \multicolumn{2}{|c|}{5.026} & \\
\hline $10 \%$ & 5.026 & \multicolumn{2}{|c|}{$5.433 \mathrm{Obs}$} & 17 \\
\hline $25 \%$ & 8.590 & & Sum of Wgt. & 17 \\
\hline \multirow[t]{2}{*}{$50 \%$} & 13.362 & & Mean & 14.943 \\
\hline & \multicolumn{2}{|c|}{ Largest } & Std. Dev. & 9.227 \\
\hline $75 \%$ & 20.598 & \multicolumn{2}{|c|}{21.760} & \\
\hline $90 \%$ & 30.637 & \multicolumn{2}{|c|}{23.000 Variance } & 85.142 \\
\hline $95 \%$ & 33.137 & \multicolumn{2}{|c|}{30.637 Skewness } & 0.394 \\
\hline $99 \%$ & 33.137 & \multicolumn{2}{|c|}{33.137 Kurtosis } & 2.314 \\
\hline \multicolumn{5}{|c|}{ After Matching } \\
\hline \multicolumn{2}{|c|}{ Percentiles } & lest & & \\
\hline $1 \%$ & 0.000 & \multicolumn{2}{|c|}{0.000} & \\
\hline $5 \%$ & 0.000 & \multicolumn{2}{|c|}{0.000} & \\
\hline $10 \%$ & 0.000 & \multicolumn{2}{|c|}{0.609 Obs } & 17 \\
\hline $25 \%$ & 1.778 & & Sum of Wgt. & 17 \\
\hline \multirow[t]{2}{*}{$50 \%$} & 3.820 & & Mean & 4.781 \\
\hline & \multicolumn{2}{|c|}{ Largest } & Std. Dev. & 4.754 \\
\hline $75 \%$ & 6.982 & & & \\
\hline $90 \%$ & 10.253 & & Variance & 22.601 \\
\hline $95 \%$ & 18.576 & & Skewness & 1.482 \\
\hline $99 \%$ & 18.576 & & Kurtosis & 5.102 \\
\hline
\end{tabular}

Source: own estimations based on the October EPH, INDEC. 